\title{
Runx2 transcriptome of prostate cancer cells: insights into invasiveness and bone metastasis
}

\author{
Sanjeev K Baniwal ${ }^{1,4,6^{*}}$, Omar Khalid ${ }^{1,4,6}$, Yankel Gabet ${ }^{1,4,6}$, Ruchir R Shah ${ }^{7,8}$, Daniel J Purcell ${ }^{1,6}$, Deepak Mav ${ }^{7}$, \\ Alice E Kohn-Gabet ${ }^{4,6}$, Yunfan Shi ${ }^{4,6}$, Gerhard A Coetzee ${ }^{3,5,6}$, Baruch Frenkel ${ }^{1,2,4,6^{*}}$
}

\begin{abstract}
Background: Prostate cancer (PCa) cells preferentially metastasize to bone at least in part by acquiring osteomimetic properties. Runx2, an osteoblast master transcription factor, is aberrantly expressed in PCa cells, and promotes their metastatic phenotype. The transcriptional programs regulated by Runx2 have been extensively studied during osteoblastogenesis, where it activates or represses target genes in a context-dependent manner. However, little is known about the gene regulatory networks influenced by Runx2 in PCa cells. We therefore investigated genome wide mRNA expression changes in PCa cells in response to Runx2.

Results: We engineered a C4-2B PCa sub-line called C4-2B/Rx2 ${ }^{\text {dox }}$, in which Doxycycline (Dox) treatment stimulates Runx2 expression from very low to levels observed in other PCa cells. Transcriptome profiling using whole genome expression array followed by in silico analysis indicated that Runx2 upregulated a multitude of genes with prominent cancer associated functions. They included secreted factors (CSF2, SDF-1), proteolytic enzymes (MMP9, CST7), cytoskeleton modulators (SDC2, Twinfilin, SH3PXD2A), intracellular signaling molecules (DUSP1, SPHK1, RASD1) and transcription factors (Sox9, SNAI2, SMAD3) functioning in epithelium to mesenchyme transition (EMT), tissue invasion, as well as homing and attachment to bone. Consistent with the gene expression data, induction of Runx2 in C4-2B cells enhanced their invasiveness. It also promoted cellular quiescence by blocking the G1/S phase transition during cell cycle progression. Furthermore, the cell cycle block was reversed as Runx2 levels declined after Dox withdrawal.

Conclusions: The effects of Runx2 in C4-2B/Rx2 ${ }^{\text {dox }}$ cells, as well as similar observations made by employing LNCaP, 22RV1 and PC3 cells, highlight multiple mechanisms by which Runx2 promotes the metastatic phenotype of $\mathrm{PCa}$ cells, including tissue invasion, homing to bone and induction of high bone turnover. Runx 2 is therefore an attractive target for the development of novel diagnostic, prognostic and therapeutic approaches to PCa management. Targeting Runx2 may prove more effective than focusing on its individual downstream genes and pathways.
\end{abstract}

\section{Introduction}

Runx2 together with Runx1 and Runx3 comprise the Runx class of transcription factors, defined by their highly homologous Runt-related DNA-binding domain. As heterodimers with $\mathrm{Cbf} \beta$, Runx proteins bind to cognate DNA elements with the consensus nucleotide sequence 5'-ACCACA in the promoters/enhancers of their target genes [1]. The three Runx proteins coordinate proliferation and differentiation of various cell

\footnotetext{
* Correspondence: baniwal@usc.edu; frenkel@usc.edu

'Department of Biochemistry \& Molecular Biology, University of Southern California, Los Angeles, USA

Full list of author information is available at the end of the article
}

types [2]. Runx1 is important for hematopoiesis [3,4]; Runx2 is pivotal in osteogenesis [1,5,6]; and Runx3 is critical for neurogenesis [7], thymopoiesis [4], and maintenance of the gastric epithelium $[4,8]$. While promoting specific cellular phenotypes, Runx proteins have evolved to inhibit cell proliferation. Runx3 is a bona fide tumor suppressor [9] as down-regulation of its promoter by hypermethylation contributes to the development of gastric cancer [10,11]. Ablation of Runx1 activity leads to leukemia [12] and disruption of Runx2 results in deregulated cell proliferation and immortalization [13-17]. Paradoxically, Runx2 is also implicated in carcinogenesis. In a mouse screen for c-Myc-collaborating

\section{Biomed Central}


oncogenes, MLV-induced leukemia occurred most frequently when the provirus integrated into the Runx2 locus resulting in its ectopic expression [18]. It was suggested that Runx2 initially provides the cells with a survival advantage, and its anti-mitogenic activity is counteracted by the CD2-Myc transgene present in the mouse model used for this screen $[2,19]$. Therefore, Runx2-mediated tumorigenesis likely requires additional loss of check-point genes such as $\operatorname{Trp} 53$ or improper regulation of an oncogene such as c-Myc [19].

Runx2 has been extensively studied in the context of osteoblastogenesis from mesenchymal progenitors, where as a master regulator it stimulates the expression of various bone matrix components such as osteocalcin and bone sialoprotein (BSP) [20]. Runx $2^{-/-}$mice die soon after birth due to the lack of differentiated osteoblasts and thus a mineralized skeleton $[1,5,6]$. Runx2 haploinsufficiency in humans causes the rare skeletal disorder Cleidocranial Dysplasia [21]. In search for hints to explain the high predilection of prostate and breast cancer to metastasize to bone, investigators have noticed ectopic expression of Runx2 and some of its target genes in biopsies from advanced tumors and their derivative cell lines [22-26]. In a mouse model of PCa, conditional deletion of Pten in prostate epithelial cells resulted in the development of tumors with progressive increase in Runx2 expression [27]. Among the osteomimetic properties of prostate and breast cancer cells are expression of the Runx2 target genes MMP9 [28], BSP [29] and VEGFA [30], as well as induction of mineralization [25].

In addition to promoting osteoblast differentiation, Runx2 drives the expression of osteoclastogenic signals, both in osteoblasts [31,32] and in the PC3 bone metastasis-derived PCa cell line [22]. PC3 cells robustly express Runx2 [33], and its silencing decreased their osteoclastogenic property in vitro and their growth within the bone microenvironment in vivo [22]. Runx2 also promotes metastatic aspects not necessarily related to bone. Invasion of PC3 cells through Matrigel $^{\mathrm{TM}}$, a basement membrane-like preparation, decreased after Runx2 silencing [22], and its ectopic expression in mammary epithelial cells increased their proliferation and disrupted their normal acinar organization [34]. An oncogenic role for Runx2 has also been suggested in tumors that do not exhibit high predilection to bone, including pancreatic ductal adenocarcinoma [35] and thyroid papillary carcinoma [36].

Whereas Runx2 is being increasingly recognized as a pro-metastatic factor, little is known about the underlying transcriptional programs. To establish gene regulatory networks downstream of Runx2 in aggressive PCa, we analyzed gene expression in response to Runx2 in the C4-2B PCa cell line. These cells are castration- resistant derivatives of the androgen-dependent $\mathrm{LNCaP}$ cells, and serve as a model for the aggressive stage of bone metastatic PCa $[37,38]$. Although C4-2B cells express Runx2 at levels higher than LNCaP cells [25], these levels are far lower than those observed in PC3 cells or osteoblasts [22]. We therefore engineered a C4$2 \mathrm{~B}$ sub-line that allowed us to profile gene expression after induction of Runx2 with Doxycycline to levels seen in PC3 cells. Remarkably, the most significant changes were the up-regulation of genes implicated in cancer progression and cellular movement, and the down-regulation of genes involved in cell cycle progression. Consistent with these changes in gene expression, Runx2 enhanced PCa cell invasiveness and inhibited their proliferation.

\section{Results and Discussion}

\section{Establishment of C4-2B PCa cells with conditional Runx2 expression}

To establish a C4-2B cell line that conditionally expresses Runx2, we employed the recently described lentivirus-based pSLIK vector system, which allows tight Doxycycline (Dox)-inducible, RNA PolII-mediated transcription of a gene of interest [39]. C4-2B cells were transduced with Flag-tagged Runx2-encoding lentiviruses (Figure $1 \mathrm{~A}$ ), resulting in the $\mathrm{C} 4-2 \mathrm{~B} / \mathrm{Rx} 2^{\mathrm{dox}}$ subline. As control, we established the $C 4-2 B / R \times 2-M^{\text {dox }}$ subline, where Dox treatment induced expression of the transcriptionally inactive Flag-Runx2-M (Figure 1A) [40]. Western blot analysis with anti-Flag antibodies confirmed roughly equal expression levels of the wild type and mutant Runx2 proteins, which were strictly and dose-dependently regulated by Dox (Figure 1B). RT-qPCR analysis revealed that the Dox treatment increased Runx 2 mRNA by $\sim 20$-fold compared to its endogenous levels, and that the induced level was comparable to that observed in the PC $3^{\text {high }}$ sub-line (Figure $1 C)$. Western analysis using anti-Runx2 antibodies indicated that the level of endogenous Runx2 protein was negligible in untreated C4-2B cells, and that Dox induced expression of the exogenous Runx2 to the levels normally found in osteoblasts (Figure 1D) [41].

The transcriptional activity of Dox-induced Runx2 was initially assessed using luciferase reporter assay (Figure $1 \mathrm{E})$. In the reporter plasmid 6XOSE2-Luc, luciferase expression was controlled by six copies of the osteoblast-specific element 2 (OSE2) from the Runx2-regulated osteocalcin (OC) gene promoter [42]. In the absence of Dox, 6XOSE2-luc activity was indistinguishable from the background luciferase activity observed without any cell extract, suggesting lack of endogenous Runx2 activity (Figure 1E). The luciferase reporter was strongly stimulated by WT but not by the mutant form of Runx2 (Figure 1E). As shown in Figure 1F, Runx2 
A

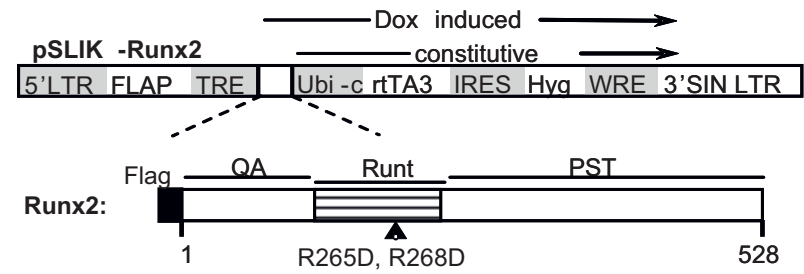

$\mathrm{B}$
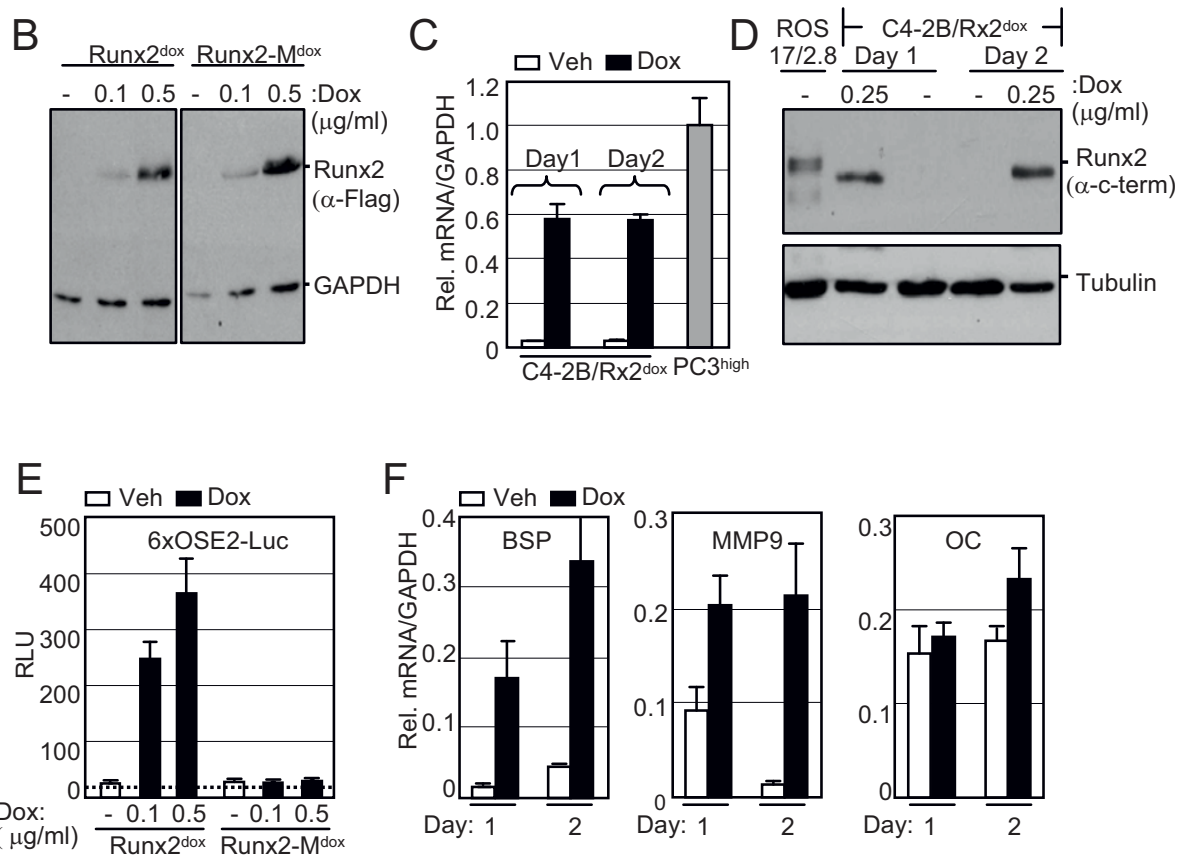

Figure 1 Establishment of $\mathbf{C} 4-\mathbf{2 B} / \mathbf{R x} \mathbf{2}^{\text {dox }}$ sub-line with conditional Runx2 expression. A, Schematic diagram of the pSLIK-based lentiviral vector. Initially developed for expression of shRNAs [39] the pSLIK vector was used in the present study to express Runx2. The Hygromycin resistance marker (Hyg) and the Dox-dependent activator protein rtTA3 are constitutively expressed under the control of the Ubi-c promoter. Upon treatment with Dox, rtTA binds to its tetracycline responsive elements (TRE) and drives expression of the inserted CDNA (Flag-Runx2). The Runx2 block diagram depicts its glutamine/alanine-rich QA domain, the DNA-binding Runt domain, and the proline/serine/threonine-rich PST domain. Arrowhead indicates the position of the R265D and R268D mutations in Runx2-M, which eliminate Runx2's DNA binding function. B, Whole cell extracts, prepared from $C 4-2 B / R \times 2^{\text {dox }}$ and $C 4-2 B / R \times 2-M^{\text {dox }}$ cells treated with the indicated concentrations of Dox, were subjected to western blot analysis using anti-Flag antibodies. C, Total RNA was extracted from C4-2B/Rx2 ${ }^{\text {dox }}$ cells treated with Dox or vehicle, as well as from PC3 ${ }^{\text {high }}$ cells, and the mRNA levels of Runx2 (and GAPDH as control) were measured by RT-qPCR. D, Whole cell extracts were prepared from C4$2 B / R \times 2^{\text {dox }}$ cells treated with Dox as indicated and from ROS 17.8/2 osteoblastic cells [41], and subjected to western blot analysis using anti-Runx2 antibodies. The same blot was re-probed with anti-Tubulin antibodies as loading control. E, C4-2B/Rx2 ${ }^{\text {dox }}$ and C4-2B/Rx2-M ${ }^{\text {dox }}$ cells were transiently transfected with the 6XOSE2-luciferase reporter plasmid and subjected to luciferase assay. Dotted line represents the background luciferase activity with no cell extract. F, C4-2B/Rx2 ${ }^{\text {dox }}$ cells were treated with Dox and levels of the indicated transcripts were measured by RTqPCR and corrected for that of GAPDH. In Figure 1, bars represent Mean \pm SEM $(n=3)$ from a representative experiment, which was repeated at least three times with similar results. Abbreviations used: Dox, Doxycycline; Veh, vehicle; BSP, Bone Sialoprotein; MMP9, Matrix Metalloprotein-9; OC, Osteocalcin.

also stimulated transcription of its endogenous target genes Bone Sialoprotein (BSP) [29] and Matrix Metalloprotease-9 (MMP9) [28]. These genes were not stimulated in the Dox-treated C4-2B/Rx2- $\mathrm{M}^{\text {dox }}$ cells (data not shown). Interestingly, Runx2 did not significantly enhance the expression of OC (Figure 1F) and Alkaline
Phophatase (ALP; data not shown), although these genes are strongly stimulated by Runx 2 in osteoblasts $[1,43]$. This observation reflects cell type-dependent Runx2-mediated transcriptional control, and is consistent with the results of Yeung et al. [33], who demonstrated that in PC3 cells the OC promoter is responsive 
to the transcription factors AP-1 and SP1, but not Runx2. To identify Runx2-regulated genes and pathways in advanced PCa cells in an unbiased manner, we subjected $\mathrm{C} 4-2 \mathrm{~B} / \mathrm{Rx} 2^{\mathrm{dox}}$ cells to global gene expression profiling.

\section{Runx2-regulated global gene expression and in silico assessment of associated pathways}

$\mathrm{C} 4-2 \mathrm{~B} / \mathrm{Rx} 2^{\text {dox }}$ cells were subjected to microarray gene expression analysis after one- and two- days of treatment with either Dox or vehicle in biological quadruplicates (a total of 16 samples). Of 24,526 probes represented in the microarray, 532 genes showed $\geq 2$ fold increased expression and 378 genes showed $\geq 2$-fold decreased expression with high statistical significance $(p<0.008)$ on either day of treatment (see additional file 1). RT-qPCR analysis of 50 representative genes conformed to the microarray data (Table 1 and additional file 2).

An unsupervised hierarchical analysis of these 910 upand down-regulated genes resulted in a clear separation between the Dox-treated and control samples (Figure 2). The variation among the biological quadruplicates was small, indicating the overall robustness of the methodology utilized. Gene clusters showing changes in expression pattern with respect to time and Dox treatment were clearly discernable. In general, changes observed on day 1 of treatment were maintained or intensified by day 2 .

We next employed the Ingenuity Pathway Analysis $\left(\mathrm{IPA}^{\mathrm{Tm}}\right)$ platform to indentify disease pathways, as well as molecular and cellular functions associated with Runx2regulated genes. The analysis suggested 'cancer' as the disease most significantly associated with both the upand the down-regulated gene groups (Table 2). A total of 248 genes, half from each group, had highly significant cancer related function (see additional file 3). Additionally, the up-regulated genes were strongly associated with genetic disorders, inflammatory responses, and gastrointestinal diseases (Table 2A). Among the most significant molecular and cellular functions, cellular movement, cell death, cellular growth, and proliferation were associated with the up-regulated genes, whereas cell cycle, cell death, cellular assembly and DNA replication functions were associated with the down-regulated genes (Table 2B).

\section{Runx2-modulated genes are involved in tumor metastasis Promotion of tissue invasion, metastasis and cytoskeleton dynamics}

The major functions reported for the up-regulated genes belonged to cancer progression (Table 2). Importantly, these genes encode transcriptional regulators, cytoskeletal components, signaling molecules and peptidases, which have been implicated in tumor metastasis (Table 1). The transcription factors Sox9 and SNAI2, and the extracellular-matrix (ECM) protein $\mathrm{LCN} 2$, all major regulators of epithelial-to-mesenchymal transition (EMT) $[44,45]$, were up-regulated by $\sim 4$-fold after one day and by $>6$-fold after two days of Runx 2 induction, and their upregulation was confirmed by RT-qPCR (Table 1). However, the functional significance of these EMT markers requires further investigation in light of the unexpected increase in E-cadherin mRNA (see additional file 4). Runx2 also enhanced the expression levels of multiple transcripts encoding matrix modifying peptidases (Table 1). These included MMP9, a known Runx2 target in BCa cells [28] and aspartyl proteases with fibronectin degrading activities such as Prolactin Induced Protein (PIP) and Pepsinogen (PGC) $[46,47]$. The latter two showed a rapid $\sim 10$-fold increase within 24 hours (Table 1) and PIP exhibited the highest change (79-fold) in response to Runx 2 on day 2 (Table 1 and additional file 2). PIP protein in the $\mathrm{C} 4-2 \mathrm{~B} / \mathrm{Rx} 2^{\text {dox }}$ culture supernatant was below detectable levels under control conditions, but was readily detected after induction of Runx2 (Figure 3). We also found increased transcript levels for Cystatin 7 (CST7), S100A4 and SMAD3, with a mild $\sim 3$-fold increase on day 1 , but a robust $>20$-fold increase on day 2 (Table 1 ). These genes function as metastasis promoters $[48,49]$. Interestingly, S100A4 and SMAD3 physically interact to potentiate cancer cell invasiveness [50].

Runx2 also up-regulated genes involved in cellular movement and cytoskeleton remodeling (Table 1). SH3PXD2A, which was up-regulated by 7 -fold on day 2 , is a scaffold protein involved in the formation of invadopedia $[51,52]$, which are matrix digesting, actin rich, short lived protrusions observed in osteoclasts and cancer cells [53]. Runx2 up-regulated by $>9$-fold the transcripts for Nav2, a scaffold protein crucial for actin cytoskeleton remodeling [53]. Other genes that were upregulated by $>3$-fold, with known roles in actin cytoskeleton dynamics included ESPN, which interacts with the Src-homology 3 (SH3) adaptor proteins to regulate cytoskeletal actin functions [54]; MAP1B, known to maintain cytoskeletal integrity [55]; LIMA1, which cross-links actin monomers [56]; and PTK9L (a.k.a. twinfiln), which sequesters ADP-actin monomers in the cytoplasm and delivers them to sites of rapid actin-filament assembly [57].

\section{Metastasis to bone and modification of the bone microenvironment}

The expression of SDF-1 and its receptor CXCR7 was enhanced by $>5$-fold based on the microarray analysis and by $>20$-fold based on the RT-qPCR results (Table 1). Runx2-induced SDF-1 protein was also detectable in the culture supernatant (Figure 3). SDF-1 signaling is 
Table 1 Genes most responsive to Runx2 in C4-2B cells

\begin{tabular}{|c|c|c|c|c|c|c|c|c|}
\hline \multirow[t]{2}{*}{$\begin{array}{c}\text { Gene } \\
\text { ID }\end{array}$} & \multirow[t]{2}{*}{ Symbol } & \multirow[t]{2}{*}{ Gene Name } & \multirow{2}{*}{$\begin{array}{l}\text { Anova } \\
p \text { value }\end{array}$} & \multicolumn{3}{|c|}{$\begin{array}{l}\text { Fold } \\
\text { change }\end{array}$} & \multirow[t]{2}{*}{ Description of cancer related or other major function } & \multirow[t]{2}{*}{ Reference } \\
\hline & & & & । & $\|$ & $q$ & & \\
\hline \multicolumn{9}{|c|}{ Transcription regulators } \\
\hline 7069 & THRSP & $\begin{array}{l}\text { Thyroid hormone } \\
\text { responsive }\end{array}$ & $3.5 \mathrm{E}-06$ & 7 & 5 & & $\begin{array}{l}\text { Transcription of enzymes involved in tumor lipid } \\
\text { metabolism }\end{array}$ & \\
\hline 29947 & DNMT3L & $\begin{array}{l}\text { DNA (cytosine-5- } \\
\text { )-methyltransferase } \\
\text { 3-like }\end{array}$ & $5.5 \mathrm{E}-08$ & 5 & 6 & $\begin{array}{l}> \\
50\end{array}$ & DNA methylation, nucleic acid metabolic process & \\
\hline 4091 & SMAD6 & $\begin{array}{l}\text { SMAD family } \\
\text { member } 6\end{array}$ & $8.1 \mathrm{E}-10$ & 5 & 4 & & $\begin{array}{l}\text { Cell communication, TGF-beta receptor signaling } \\
\text { pathway }\end{array}$ & \\
\hline 6591 & SNAI2 & $\begin{array}{l}\text { Snail homolog } 2 \\
\text { (Drosophila) }\end{array}$ & $8.8 \mathrm{E}-07$ & 4 & 12 & 6 & Promotes EMT by repressing E-cadherin transcription & {$[44]$} \\
\hline 6662 & sox9 & $\begin{array}{l}\text { SRY (sex } \\
\text { determining region } \\
\text { Y)-box } 9\end{array}$ & 4.4E-07 & 4 & 6 & 17 & $\begin{array}{l}\text { Promotes chondrocyte differentiation, cell migration, and } \\
\text { EMT }\end{array}$ & [110] \\
\hline 7025 & NR2F1 & $\begin{array}{l}\text { Nuclear receptor } \\
\text { subfamily } 2 \text {, }\end{array}$ & $3.5 \mathrm{E}-07$ & 3 & 14 & 2 & $\begin{array}{l}\text { Ligand-dependent receptor, regulation of transcription } \\
\text { termination }\end{array}$ & \\
\hline 678 & ZFP36L2 & $\begin{array}{l}\text { Zinc finger protein } \\
36, \mathrm{C} 3 \mathrm{H} \text { type-like } 2\end{array}$ & 4.1E-09 & 3 & 10 & & Regulation of RNA metabolic process & \\
\hline 4088 & SMAD3 & $\begin{array}{l}\text { SMAD family } \\
\text { member } 3\end{array}$ & $6.3 \mathrm{E}-10$ & 3 & 7 & 25 & Signal transducer downstream of TGF- $\beta$ receptors & \\
\hline 283248 & RCOR2 & REST corepressor 2 & $2.9 \mathrm{E}-06$ & 3 & 7 & & Negative regulation of transcription & \\
\hline 10217 & CTDSPL & $\begin{array}{l}\text { Small CTD } \\
\text { phosphatase } 3\end{array}$ & $1.9 \mathrm{E}-09$ & -2 & -3 & & $\begin{array}{l}\text { Phosphatase, dephosphorylates Rb, suppresses cellular } \\
\text { growth }\end{array}$ & \\
\hline 1870 & $\mathrm{E} 2 \mathrm{~F} 2$ & $\begin{array}{l}\text { E2F transcription } \\
\text { factor } 2\end{array}$ & $8.2 \mathrm{E}-10$ & -2 & -5 & -4 & $\begin{array}{l}\text { Transcription activator, regulation of cell cycle } \\
\text { progression, proliferation }\end{array}$ & \\
\hline 90390 & MED30 & $\begin{array}{l}\text { Mediator complex } \\
\text { subunit } 30\end{array}$ & $<1.0 \mathrm{E}-12$ & -2 & -3 & & $\begin{array}{l}\text { Transcription activator, Androgen receptor signaling } \\
\text { pathway }\end{array}$ & \\
\hline 4609 & MYC & $\begin{array}{l}\text { V-myc } \\
\text { myelocytomatosis } \\
\text { viral oncogene }\end{array}$ & $2.9 \mathrm{E}-07$ & -2 & -3 & -2 & Positive regulation of cell proliferation, apoptosis & {$[111,112]$} \\
\hline 29893 & PSMC3IP & $\begin{array}{l}\text { PSMC3 interacting } \\
\text { protein }\end{array}$ & $3.5 \mathrm{E}-08$ & -2 & -4 & & Gene expression from RNA Polll & \\
\hline 4602 & MYB & $\begin{array}{l}\text { Viral oncogene } \\
\text { homolog (avian) }\end{array}$ & $1.6 \mathrm{E}-08$ & -3 & -5 & -3 & G1/S transition of mitotic cell cycle & \\
\hline 4824 & NKX3-1 & NK3 homeobox 1 & $3.7 \mathrm{E}-08$ & -3 & -3 & & $\begin{array}{l}\text { Transcription repressor, loss induces prostate } \\
\text { tumorigenesis }\end{array}$ & \\
\hline \multicolumn{9}{|c|}{ Intracellular signaling, cell cycle and proliferation } \\
\hline 51655 & RASD1 & $\begin{array}{l}\text { RAS, } \\
\text { dexamethasone- } \\
\text { induced } 1\end{array}$ & $6.8 \mathrm{E}-12$ & 26 & 19 & $\begin{array}{l}> \\
50\end{array}$ & $\begin{array}{l}\text { Ras related, suppresses cell proliferation, inhibits tumor } \\
\text { growth }\end{array}$ & [92] \\
\hline 6446 & SGK & $\begin{array}{l}\text { Serum/ } \\
\text { glucocorticoid } \\
\text { regulated kinase } 1\end{array}$ & $<1.0 \mathrm{E}-12$ & 19 & 45 & & Cellular $\mathrm{Na}^{+}$ion homeostasis, cell survival & \\
\hline 57007 & CXCR7 & $\begin{array}{l}\text { Chemokine } \\
\text { receptor } 7\end{array}$ & $9.2 \mathrm{E}-11$ & 8 & 12 & 30 & $\begin{array}{l}\text { Receptor for SDF-1, GPCR, enhanced integrin activation } \\
\text { and tumor growth }\end{array}$ & {$[113]$} \\
\hline 1843 & DUSP1 & $\begin{array}{l}\text { Dual specificity } \\
\text { phosphatase } 1\end{array}$ & $9.1 \mathrm{E}-13$ & 8 & 8 & 10 & Regulator of cell cycle, response to stress & [114] \\
\hline 5580 & PRKCD & $\begin{array}{l}\text { Protein kinase } \mathrm{C} \text {, } \\
\text { delta }\end{array}$ & $2.0 \mathrm{E}-11$ & 6 & 5 & 12 & $\begin{array}{l}\text { Serine-Threonine Kinase, cell proliferation, cell } \\
\text { contraction }\end{array}$ & \\
\hline 55890 & GPRC5C & $\begin{array}{l}\text { G protein-coupled } \\
\text { receptor, family C }\end{array}$ & $1.3 \mathrm{E}-09$ & 5 & 5 & 25 & GPCR, cell communication & \\
\hline 10461 & MERTK & $\begin{array}{l}\text { C-mer proto- } \\
\text { oncogene tyrosine } \\
\text { kinase }\end{array}$ & $6.2 \mathrm{E}-10$ & 4 & 6 & 39 & Protein amino acid phosphorylation & \\
\hline 5920 & RARRES3 & $\begin{array}{l}\text { Retinoic acid } \\
\text { receptor responder } \\
3\end{array}$ & $4.3 \mathrm{E}-08$ & 3 & 8 & 40 & Negative regulation of cell proliferation & \\
\hline
\end{tabular}


Table 1 Genes most responsive to Runx2 in C4-2B cells (Continued)

\begin{tabular}{|c|c|c|c|c|c|c|c|c|}
\hline 1903 & EDG3 & $\begin{array}{l}\text { Sphingosine-1- } \\
\text { phosphate } \\
\text { receptor } 3\end{array}$ & $4.8 \mathrm{E}-10$ & 3 & 7 & & $\begin{array}{l}\text { GPCR, enhances tumor growth, cell migration, and } \\
\text { angiogenesis }\end{array}$ & {$[77-79,115,116]$} \\
\hline 8877 & SPHK1 & $\begin{array}{l}\text { Sphingosine kinase } \\
1\end{array}$ & $7.5 \mathrm{E}-09$ & 3 & 12 & 36 & $\begin{array}{l}\text { Kinase for the production of S1P, enhances tumor } \\
\text { growth, cell migration, and angiogenesis, PCa cell } \\
\text { survival against chemotherapy, osteoclast chemotaxis }\end{array}$ & {$[77-79,115,116]$} \\
\hline 7049 & TGFBR3 & $\begin{array}{l}\text { Transforming } \\
\text { growth factor, } \beta \\
\text { receptor III }\end{array}$ & 7.1E-09 & 3 & 4 & 12 & Negative regulation of TGF $\beta$ receptor signaling pathway & \\
\hline 4921 & DDR2 & $\begin{array}{l}\text { Discoidin domain } \\
\text { receptor tyrosine } \\
\text { kinase } 2\end{array}$ & $2.9 \mathrm{E}-05$ & 2 & 5 & & Collagen binding, cell proliferation & \\
\hline 1017 & CDK2 & $\begin{array}{l}\text { Cyclin-dependent } \\
\text { kinase } 2\end{array}$ & $1.3 \mathrm{E}-03$ & -2 & -3 & -4 & Kinase, mitotic cell cycle, cell proliferation & \\
\hline 55038 & CDCA4 & $\begin{array}{l}\text { Cell division cycle } \\
\text { associated } 4\end{array}$ & $7.2 \mathrm{E}-08$ & -2 & -4 & -4 & $\begin{array}{l}\text { Repressor of E2F-dependent transcriptional activation } \\
\text { and cell proliferation }\end{array}$ & \\
\hline 5997 & RGS2 & $\begin{array}{l}\text { Regulator of G- } \\
\text { protein signaling 2, } \\
24 \mathrm{kDa}\end{array}$ & $9.0 \mathrm{E}-09$ & -3 & -3 & & Cell cycle, GPCR signaling pathway, cell communication & \\
\hline 25805 & BAMBI & $\begin{array}{l}\text { BMP and activin } \\
\text { membrane-bound } \\
\text { inhibitor homolog } \\
\text { (Xenopus laevis) }\end{array}$ & 9.7E-10 & -2 & -3 & & TGF- $\beta$ signaling pathway & \\
\hline \multicolumn{9}{|c|}{ Cellular movement, adhesion, invasion, cytoskeleton remodeling } \\
\hline 89797 & NAV2 & Neuron navigator 2 & $6.7 \mathrm{E}-09$ & 9 & 10 & 29 & $\begin{array}{l}\text { Scaffold protein, actin cytoskeleton remodeling, nervous } \\
\text { system development }\end{array}$ & [53] \\
\hline 27111 & SDCBP2 & $\begin{array}{l}\text { Syndecan binding } \\
\text { protein } 2\end{array}$ & $2.2 \mathrm{E}-03$ & 6 & 15 & & $\begin{array}{l}\text { Binds SDC2, regulates cell adhesion and communication } \\
\text { with ECM molecules }\end{array}$ & {$[84,85]$} \\
\hline 11344 & PTK9L & Twinfilin & $9.0 \mathrm{E}-10$ & 6 & 5 & 11 & Actin-binding protein, cytoskeleton organization & {$[57]$} \\
\hline 83715 & ESPN & Espin & $2.1 \mathrm{E}-08$ & 5 & 8 & $\begin{array}{l}> \\
50\end{array}$ & $\begin{array}{l}\text { Actin-binding-bundling protein, actin cytoskeleton } \\
\text { dynamics, cell locomotion }\end{array}$ & {$[54,117,118]$} \\
\hline 51474 & LIMA1 & $\begin{array}{l}\text { Eplin, LIM domain } \\
\text { and actin binding } \\
1\end{array}$ & $3.0 \mathrm{E}-10$ & 4 & 5 & 15 & $\begin{array}{l}\text { Cytoskeleton-associated protein, regulation of actin } \\
\text { filament depolymerization }\end{array}$ & {$[56]$} \\
\hline 8829 & NRP1 & Neuropilin 1 & $4.1 \mathrm{E}-08$ & 4 & 11 & 40 & $\begin{array}{l}\text { TM, coreceptor for VEGF, collagen binding, cell adhesion, } \\
\text { invasion }\end{array}$ & [119] \\
\hline 4582 & MUC1 & $\begin{array}{l}\text { Mucin 1, cell } \\
\text { surface associated }\end{array}$ & $1.1 \mathrm{E}-09$ & 4 & 4 & & TM, cell adhesion, invasion & {$[120]$} \\
\hline 4131 & MAP1B & $\begin{array}{l}\text { Microtubule- } \\
\text { associated protein } \\
\text { 1B }\end{array}$ & 7.1E-09 & 3 & 9 & 18 & Trans-membrane glycoprotein, cytoskeleton organization & {$[55,121]$} \\
\hline 9644 & SH3PXD2A & $\begin{array}{l}\text { SH3 and PX } \\
\text { domains } 2 \mathrm{~A}\end{array}$ & $1.4 \mathrm{E}-09$ & 3 & 7 & & $\begin{array}{l}\text { Adaptor protein, ECM degradation by actin based } \\
\text { invadopedia formation }\end{array}$ & {$[122]$} \\
\hline 6275 & S100A4 & $\begin{array}{l}\text { S100 calcium } \\
\text { binding protein A4 }\end{array}$ & $2.6 \mathrm{E}-08$ & 2 & 24 & $\begin{array}{l}> \\
50\end{array}$ & $\begin{array}{l}\text { EF-hand calcium-binding protein, promotes cell motility, } \\
\text { tumor metastasis }\end{array}$ & [49] \\
\hline 6383 & SDC2 & Syndecan 2 & $3.1 \mathrm{E}-06$ & 2 & 5 & 32 & $\begin{array}{l}\text { TM, bind signaling factors, cell adhesion, angiogenesis, } \\
\text { ECM degradation }\end{array}$ & {$[84,85]$} \\
\hline 1013 & $\mathrm{CDH} 15$ & $\begin{array}{l}\text { Cadherin } 15, \text { type } \\
\text { 1, M-cadherin }\end{array}$ & $6.9 \mathrm{E}-08$ & 2 & 5 & 21 & $\begin{array}{l}\mathrm{TM}, \mathrm{Ca}^{2+} \text { dependent intercellular adhesion, skeletal } \\
\text { muscle development }\end{array}$ & [123] \\
\hline \multicolumn{9}{|c|}{ Secreted factors } \\
\hline 1437 & CSF2 & $\begin{array}{l}\text { Colony stimulating } \\
\text { factor } 2 / \text { GM-CSF }\end{array}$ & $2.3 \mathrm{E}-09$ & 12 & 17 & $\begin{array}{l}> \\
50\end{array}$ & Cytokine, osteolytic bone metastasis & [72] \\
\hline 5225 & PGC & $\begin{array}{l}\text { Progastricsin } \\
\text { (pepsinogen C) }\end{array}$ & $3.9 \mathrm{E}-12$ & 11 & 15 & & Aspartyl proteinase & {$[47]$} \\
\hline 5304 & PIP & $\begin{array}{l}\text { Prolactin-induced } \\
\text { protein }\end{array}$ & $<1.0 \mathrm{E}-12$ & 10 & 79 & $\begin{array}{l}> \\
50\end{array}$ & Aspartyl proteinase, ligand for CD4 receptor T cells & [46] \\
\hline 8857 & FCGBP & $\begin{array}{l}\text { Fc fragment of IgG } \\
\text { binding protein }\end{array}$ & $1.5 \mathrm{E}-09$ & 5 & 9 & & Cell adhesion, cell-cell recognition & \\
\hline 6387 & CXCL12 & $\begin{array}{l}\text { Chemokine ligand } \\
12 \text { (SDF-1) }\end{array}$ & $2.2 \mathrm{E}-06$ & 5 & 7 & 23 & $\begin{array}{l}\text { Chemokine, stem cell trafficking to bone, migration, } \\
\text { metastasis of tumor cells }\end{array}$ & {$[58-65]$} \\
\hline
\end{tabular}


Table 1 Genes most responsive to Runx2 in C4-2B cells (Continued)

\begin{tabular}{|c|c|c|c|c|c|c|c|c|}
\hline 7422 & VEGFA & $\begin{array}{l}\text { Vascular } \\
\text { endothelial growth } \\
\text { factor A }\end{array}$ & $4.5 \mathrm{E}-10$ & 5 & 3 & 4 & $\begin{array}{l}\text { Growth factor, angiogenesis, cellular morphogenesis } \\
\text { during differentiation }\end{array}$ & [88-91] \\
\hline 1907 & EDN2 & Endothelin 2 & 4.3E-07 & 5 & 2 & & $\begin{array}{l}\text { Growth factor, vasoactive, G-protein signaling, smooth } \\
\text { muscle contraction }\end{array}$ & [87] \\
\hline 5654 & HTRA1 & $\begin{array}{l}\text { HtrA serine } \\
\text { peptidase } 1\end{array}$ & $6.9 \mathrm{E}-10$ & 3 & 18 & & $\begin{array}{l}\text { Serine protease, differentially expressed in osteoarthritic } \\
\text { cartillage }\end{array}$ & [124] \\
\hline 3817 & KLK2 & $\begin{array}{l}\text { Kallikrein-related } \\
\text { peptidase } 2\end{array}$ & $1.5 \mathrm{E}-08$ & 4 & 3 & & Serine protease, protein metabolic process & \\
\hline 4880 & NPPC & $\begin{array}{l}\text { Natriuretic peptide } \\
\text { precursor } C\end{array}$ & $1.8 \mathrm{E}-10$ & 4 & 17 & $\overrightarrow{50}$ & Peptide, potent natriuretic, diuretic, and vasodilating & \\
\hline 7057 & THBS1 & Thrombospondin 1 & $3.0 \mathrm{E}-10$ & 4 & 14 & $\overrightarrow{50}$ & Cell adhesion, heparin-binding, anti-angiogenic & \\
\hline 3934 & LCN2 & Lipocalin 2 & $5.1 \mathrm{E}-08$ & 4 & 10 & 5 & $\begin{array}{l}\text { ECM protein, present ligands to cell surface receptors, } \\
\text { promotes EMT }\end{array}$ & [45] \\
\hline 6462 & SHBG & $\begin{array}{l}\text { Sex hormone- } \\
\text { binding globulin }\end{array}$ & 8.7E-10 & 4 & 10 & & Steroid-binding, signal & \\
\hline 57642 & COL20A1 & $\begin{array}{l}\text { Collagen, type XX, } \\
\alpha 1\end{array}$ & $4.9 \mathrm{E}-07$ & 4 & 10 & $\begin{array}{l}> \\
50\end{array}$ & Adhesion, establishment of localization, transport & \\
\hline 4254 & KITLG & KIT ligand & $2.3 \mathrm{E}-08$ & 4 & 7 & 41 & $\begin{array}{l}\text { Hematopoietic growth factor and ligand for the KIT } \\
\text { tyrosine kinase receptor }\end{array}$ & \\
\hline 4884 & NPTX1 & $\begin{array}{l}\text { Neuronal pentraxin } \\
\text { I }\end{array}$ & $2.5 \mathrm{E}-07$ & 3 & 20 & & Cell-cell signaling, transport, establishment of localization & \\
\hline 3486 & IGFBP3 & $\begin{array}{l}\text { IGF binding } \\
\text { protein } 3\end{array}$ & $2.2 \mathrm{E}-08$ & 3 & 7 & & Regulation of cell growth, communication, apoptosis & \\
\hline 9806 & SPOCK2 & $\begin{array}{l}\text { Sparc/osteonectin, } \\
\text { cwcv, kazal-like } \\
\text { domains } \\
\text { proteoglycan } \\
\text { (testican) } 2\end{array}$ & $1.1 \mathrm{E}-06$ & 3 & 4 & & Cell differentiation, ECM organization and biogenesis & \\
\hline 8530 & CST7 & $\begin{array}{l}\text { Cystatin F } \\
\text { (leukocystatin) }\end{array}$ & 3.0E-09 & 2 & 25 & & $\begin{array}{l}\text { Competitive inhibitors of cysteine proteases, metastasis } \\
\text { associated protein }\end{array}$ & [48] \\
\hline 4885 & NPTX2 & $\begin{array}{l}\text { Neuronal pentraxin } \\
\|\end{array}$ & 7.6E-09 & 2 & 6 & & Cell-cell signaling, synaptic transmission & \\
\hline 147381 & CBLN2 & $\begin{array}{l}\text { ADAM MMP with } \\
\text { Thbs-1 motif }\end{array}$ & $5.2 \mathrm{E}-12$ & -3 & -3 & & $\begin{array}{l}\text { Peptidase, cleavage of precerebellin in the nervous } \\
\text { system }\end{array}$ & \\
\hline 6781 & STC1 & Spondin 2 & $3.6 \mathrm{E}-08$ & -3 & -3 & & ECM protein, integrin ligand, pattern recognition & \\
\hline 7035 & TFPI & $\begin{array}{l}\text { Tissue factor } \\
\text { pathway inhibitor }\end{array}$ & $3.9 \mathrm{E}-05$ & -3 & -4 & & $\begin{array}{l}\text { Kunitz-type inhibitor of blood coagulation by blocking } \\
\text { factor Xa }\end{array}$ & \\
\hline 9518 & GDF15 & $\begin{array}{l}\text { Growth } \\
\text { differentiation } \\
\text { factor } 15\end{array}$ & $1.6 \mathrm{E}-09$ & -2 & -8 & -7 & $\begin{array}{l}\text { Growth factor, TGF- } \beta \text { signaling pathway, cell } \\
\text { communication }\end{array}$ & \\
\hline
\end{tabular}

Fold changes on day 1 and day 2 are listed in columns I and II respectively, and column q lists fold changes based on RT-qPCR analysis of the day-2 samples. Major gene functions were determined using knowledge databases from OMIM (Online Mendelian Inheritance of Man), IPA ${ }^{\mathrm{TM}}$ systems and the indicated referenced literature. Abbreviations: EMT, epithelial to mesenchymal transition; TM, transmembrane; GPCR, G-protein coupled receptor; ECM, extracellular matrix.

critical for homing of hematopoietic cells to the bone marrow space and their survival in this environment [58-65]. Within one day, Runx2 also increased by 10 fold the mRNA for BSP (Figure 1F), whose abundant expression by bone metastatic tumor cells facilitates their attachment to the bone matrix [66-69]. Once settled in the bone microenvironment, the metastatic cells secrete regulatory molecules that stimulate bone turnover [70]. Remarkably, Runx2 enhanced the expression of the osteoclastogenic cytokine CSF2 by $>50$-fold within 48 hours (Table 1 ). This presumably occurred by direct binding of Runx2 to the CSF2 promoter [71].
Runx2-mediated induction of CSF2 in PCa cells likely contributes to the increased bone turnover in bone metastatic sites, similar to the role of this cytokine in breast cancer bone metastasis [72]. CSF2 production by tumor cells may also contribute to accumulation of macrophages, inflammatory $\mathrm{T}$ cells, and cytokines $[73,74]$ that exacerbate morbidity and mortality [75]. Two additional Runx2-up-regulated genes associated with osteoclast function are SPHK1, a kinase responsible for the production of sphingosine 1 phosphate (S1P), and S1P receptor $3\left(\mathrm{~S}_{\mathrm{P}} \mathrm{P}_{3}\right)$ a.k.a. EDG3 (Table 1$)$. Production of S1P in the bone microenvironment promotes 


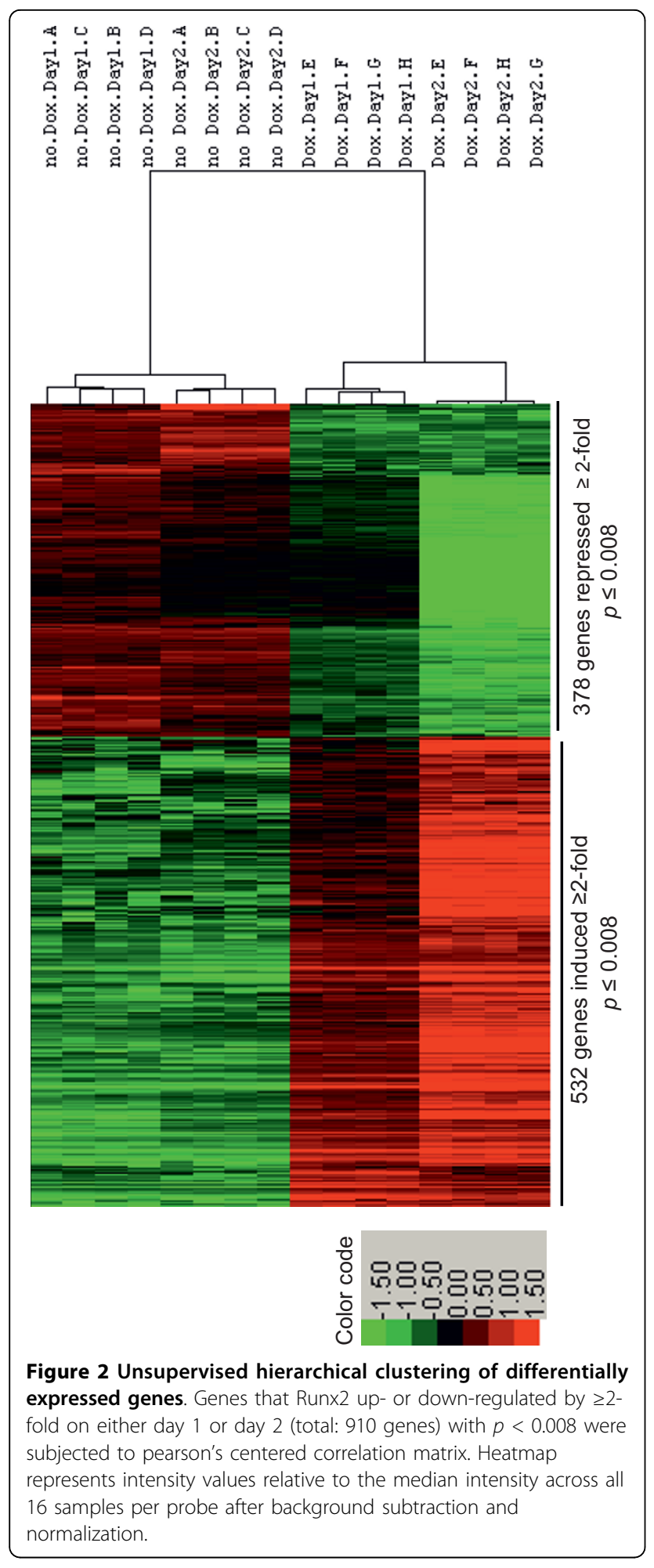

bone resorption by chemotactically attracting osteoclast precursors [76]. The SPHK $1 / \mathrm{S} 1 \mathrm{P} / \mathrm{S}_{1} \mathrm{P}_{3}$ axis plays additional roles in cancer progression, including cell growth, migration, angiogenesis, and resistance to chemotherapy [77-79]. Notably, Runx2 was the only gene differentially
Table 2 Diseases, Molecular and Cellular Functions associated with genes up-regulated $(A)$ and downregulated (B) by Runx2

\begin{tabular}{cll}
\hline $\mathbf{A}) \mathbf{2} \mathbf{2}$ fold up-regulated, total $\mathbf{5 3 2}$ genes & $\boldsymbol{p}$-value & genes \\
\hline Diseases and disorders & & \\
Cancer & $2.5 \mathrm{e}^{-07}-3.0 \mathrm{e}^{-03}$ & 124 \\
$\quad$ Genetic disorder & $5.4 \mathrm{e}^{-07}-3.0 \mathrm{e}^{-03}$ & 229 \\
$\quad$ Inflammatory response & $3.3 \mathrm{e}^{-06}-2.4 \mathrm{e}^{-03}$ & 65 \\
Molecular and cellular functions & & \\
$\quad$ Cellular movement & $9.7 \mathrm{e}^{-12}-2.5 \mathrm{e}^{-03}$ & 84 \\
Cell death & $2.6 \mathrm{e}^{-10}-3.2 \mathrm{e}^{-03}$ & 129 \\
Cellular growth, proliferation & $9.3 \mathrm{e}^{-08}-3.2 \mathrm{e}^{-03}$ & 108
\end{tabular}

B) $\geq 2$ fold down-regulated, total $\mathbf{3 7 8}$ genes

Diseases and disorders

Cancer

Gastrointestinal disease

Genetic disorder

Molecular and cellular functions

Cell cycle

$3.3 e^{-29}-4.1 e^{-03} 124$

$3.3 e^{-29}-3.7 e^{-03} 72$

$3.3 e^{-06}-3.4 e^{-03} 174$

Cellular assembly, organization

$7.1 e^{-35}-4.1 e^{-03} 102$

$1.7 e^{-18}-3.4 e^{-03} 63$

DNA replication, recombination, repair $1.7 e^{-18}-4.1 e^{-03} 101$

$\mathrm{IPA}^{\mathrm{TM}}$ analysis indicating the association of Runx2-regulated genes to a particular category identifying the indicated disease or function. The ranges of $p$ values indicate the statistical significance with which Runx2-regulated genes associate with the each category.

up-regulated in chemotherapy-resistant versus -sensitive osteosarcoma tumors [80]. Adding to this, Runx2 also repressed the expression of GDF-15, an osteoclastogenesis inhibitor [81] (Table 1). This repression was mild on day 1 (2-fold), but by day 2 GDF-15 was the most repressed gene in response to Runx2 (8-fold; Table 1 and additional file 2). Thus, Runx2-mediated alterations in gene expression may contribute to both the predilection of $\mathrm{PCa}$ to bone and the subsequent pathological increase in bone turnover, which further fuels growth of the metastatic tumors.

\section{Angiogenesis}

Runx2 has been implicated in promoting angiogenesis by stimulating VEGFA expression during bone development [30] as well as during tumorigenesis [82]. In C4-2B/Rx2 ${ }^{\text {dox }}$ cells, Runx2 increased VEGFA mRNA by 4-fold (Table 1) and the presence of VEGF in the cell culture supernatant was detectable only after Dox treatment (Figure 3). Additionally, our study revealed a 32fold upregulation of the VEGFA co-receptor Syndecan-2 (SDC2; Table 1). SDC2, which is also a Runx2 target in osteoprogenitor cells [83], is a member of the heparan sulfate proteoglycans family, and is also implicated in cell adhesion and communication [84-86]. Interestingly, VEGFA can functionally synergize with SDF-1 to promote neoangiogenesis in vivo [62]. Our microarray analysis also revealed Runx2-mediated induction of the angiogenic EDN-2 gene (Table 1). Endothelins and 


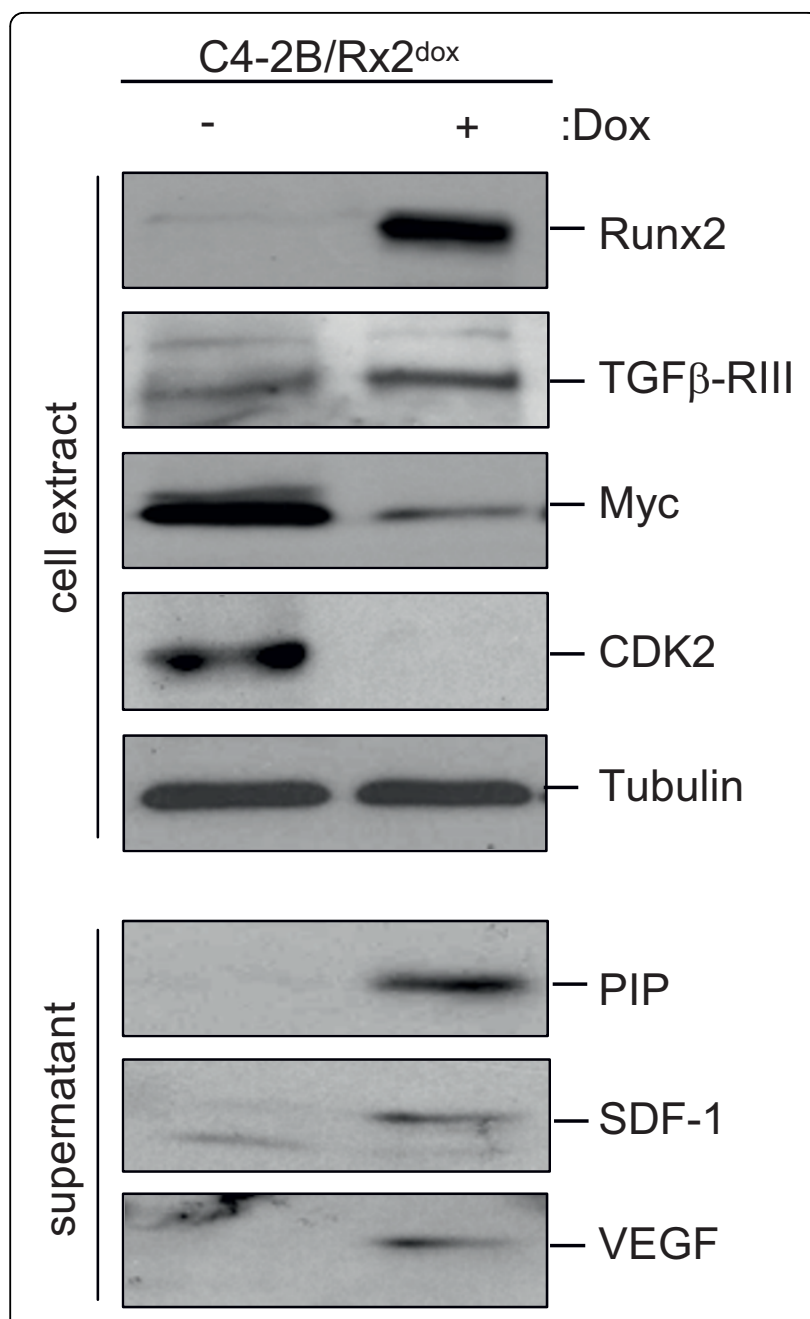

Figure 3 Runx2-regulated protein expression. $C 4-2 B / R \times 2^{\text {dox }}$ cells were treated with Dox or vehicle control, and proteins extracted as whole cell lysate (upper panel) or the supernatant (bottom panel) were subjected to western blot analysis using the indicated antibodies.

VEGFA are secreted by PCa cells to stimulate angiogenesis as well as differentiation of neighboring osteoblasts in the bone microenvironment [72,87-91].

\section{Runx2 increases the invasion potential of C4-2B cells in vitro}

Because Runx2 enhanced the expression of multiple extracellular enzymes involved in ECM degradation (Table 1), we initially tested by in-gel zymography the presence of proteases in the supernatant of Dox-treated $\mathrm{C} 4-2 \mathrm{~B} / \mathrm{Rx} 2^{\text {dox }}$ cultures. The results demonstrated that Runx2 induced several gelatin-degrading proteins, in particular one with a molecular weight of $\sim 140 \mathrm{kDa}$, the identity of which remains to be determined (Figure 4A). We further investigated whether Runx2 stimulates invasion of C4-2B/Rx2 ${ }^{\text {dox }}$ cells through Matrigel $^{\mathrm{Tx}}$, a tissue basement membrane-like preparation containing laminin, type IV collagen, heparan sulfate proteoglycans and entactin. For convenient and accurate assessment of cells that successfully invade through the Matrigel $^{\mathrm{mm}}$ membrane, we transduced the $\mathrm{C} 4-2 \mathrm{~B} / \mathrm{Rx} 2^{\text {dox }}$ cells with a lentivirus constitutively expressing luciferase. Parallel trans-wells that do not contain Matrige ${ }^{\mathrm{TM}}$ were employed as migration controls. Cells were incubated in the respective chambers in the presence or absence of Dox, and the relative migration or invasion capacity was assessed. Runx2 expression led to a 2.3-fold decrease in cell migration, but a 4.3 -fold increase in invasion

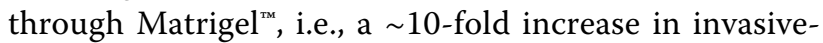
ness after adjustment for the reduced cell migration (Figure 4B). The increased invasiveness was further confirmed in an independent experiment by histological staining (Figure 4C). In parallel experiments, expression of Runx2-M in C4-2B cells showed no significant effects on either migration or invasion (data not shown). Thus, expression of transcriptionally active Runx 2 is sufficient to enhance the tissue invasion potential of C4-2B cells.

\section{Runx2 induces cellular quiescence by reversibly inhibiting} G1/S cell cycle transition

The IPA $^{\mathrm{Tm}}$ analysis of Runx2 down-regulated genes indicated their strong association with cell cycle and proliferation-related functions (Table 2B). Many of these downregulated genes, as well as several up-regulated genes, shed light on the well-established anti-proliferative activity of Runx2 [2,15-17,19]. Most striking was the $>19$ - and > 8-fold up-regulation of RASD1 and DUSP1, respectively (Table 1). RASD1 belongs to the Ras superfamily of Gproteins, and its expression in breast cancer suppressed cell growth [92]. DUSP1, a.k.a. MAP kinase phosphatase 1 (MKP1), is a dual specificity (Thr/Tyr) protein phophatase with anti-proliferative properties [93]. Among the most important cell cycle regulatory genes inhibited by Runx2 was c-Myc, with a $\sim 3$-fold decrease at the mRNA level (Table 1) and a corresponding significant decrease at the protein level (Figure 3). In line with the down-regulation of c-Myc, the mRNA encoding its cell cycle promoting targets E2F2 and CDK2 were also down-regulated (Table 1). CDK2 protein was decreased below detectability (Figure 3). To further characterize effects of Runx2 on PCa cell proliferation, we first validated by RT-qPCR the changes in the transcript levels of RASD1, DUSP1, c-Myc and E2F2 in the day-2 samples (Figure 5A). Next, we tested the effect of Runx2 on C4-2B cell proliferation by performing MTT assays every 48 hours after Doxmediated Runx2 induction. Runx2 significantly restrained cell proliferation (Figure 5B). By contrast, the transcriptionally-inactive Runx2-M did not affect proliferation (Figure 5C). Thus, Runx2 restrains PCa cell proliferation via its transcriptional activation property. 

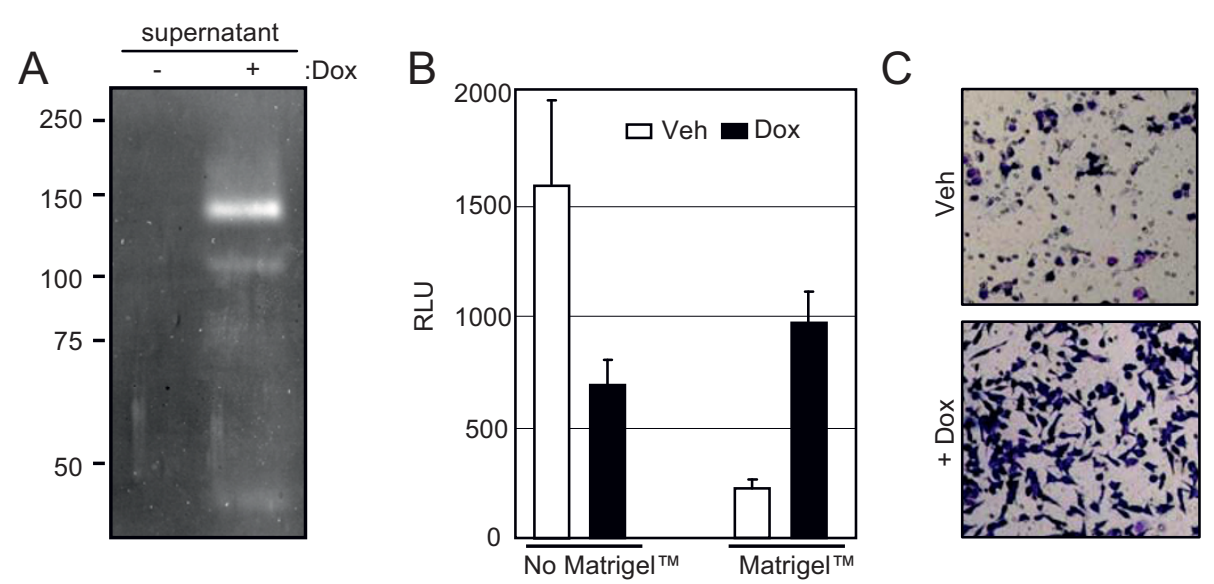

Figure 4 Runx2 enhances the invasiveness of C4-2B cells. A) Zymography of supernatants from C4-2B/Rx2 ${ }^{\text {dox }}$ cells treated with either Dox or vehicle. Negatively-stained bands represent the activity of gelatin-degrading proteases. B) $C 4-2 B / R \times 2^{\text {dox }} /$ Luc cells were incubated in the top chambers (inserts) of the Matrige $\left.\right|^{T M}$ invasion system. Cell passage through inserts with and without Matrige ${ }^{T M}$ represent invasion and migration, respectively. Identical number of cells was seeded in the indicated inserts for 24 hours and the cells that appeared on the bottom side (outside) of the inserts were solubilized in lysis buffer and subjected to luciferase assay. C) The invasion of cells through the Matrigel ${ }^{T M}$ membrane was assessed by staining with Diff-Quick ${ }^{T M}$ solution.

To delineate the anti-proliferative effect of Runx2, we tested its influence on apoptosis and cell cycle progression. Apoptosis was measured using succinyl-AMC, a fluorogenic Caspase-3 substrate. Expression of Runx2, but not Runx2-M, resulted in a transient $40 \%$ increase in apoptosis on day 4 (Figure 5D), but this could not account for the dramatic inhibition of cell proliferation (Figure 5B). Instead, fluorescence activated cell-sorting (FACS) analysis revealed a 2.2-fold decrease in the fraction of cells in the $\mathrm{S} / \mathrm{G} 2 / \mathrm{M}$ phases of the cell cycle within 24 hours of Dox treatment, and this effect persisted on day 2 (Figure 5E). Notably, the cell cycle inhibition preceded any change in apoptosis, indicating that Runx2 restrained C4-2B cell proliferation by inhibiting the G1/S phase transition of the cell cycle.

The prometastatic but anti-mitogenic properties of Runx2 in PCa cells suggest that it may initially facilitate metastasis, after which it must be degraded or antagonized (e.g. by co-repressors) to allow cell proliferation and tumor growth. Therefore, we examined if the antimitogenic effect of Runx2 was reversible by withdrawing Dox from cultures after 48 hours of treatment (Figure 5F). Dox withdrawal led to substantial clearance of Runx2 within two days, and undetectable Runx2 levels after four days (Figure 5G). This resulted in resumption of cell cycle progression (Figure $5 \mathrm{H}$ ) and cell proliferation (Figure 5I). Thus, the Runx2-regulated gene networks induce reversible cellular quiescence by blocking the G1/S phase transition of the cell cycle.

\section{Generality and Network modeling of Runx2-regulated} genes with cancer-related functions

Our study is the first to provide genome wide analysis of Runx2-regulated genes in PCa cells. Although we focused on the bone metastasis-derived C4-2B cells, similar responses to Runx2 were observed in the parental lymph node-derived LNCaP cells [38] (see additional file 5) as well as in the unrelated bone metastatic 22RV1 PCa cells (see additional file 6) [94]. Furthermore, in $\mathrm{PC} 3^{\text {high }}$ and $\mathrm{PC} 3^{\text {low }}$ cells with high and low levels of Runx2, respectively, the expression of six randomly selected Runx2 up-regulated genes from the present study correlated with Runx2 expression (see additional file 7). Together, these results suggest that our observations are relevant to various stages of PCa progression. Among the 910 genes that Runx2 up- or down-regulated by $\geq 2$ fold, $\mathrm{IPA}^{\mathrm{m}}$ identified 248 genes related to cancer with high statistical significance $(p<0.003$; Table 2 and additional file 3 ). The IPA ${ }^{\mathrm{m} x}$ analysis, as well as survey of literature on gene expression profiling in osteoblasts and fibroblasts, further suggested that the Runx2-regulated gene network in PCa (Figure 6) bears little resemblance to its targets in mesenchymal cells [43,83,95-97]. In fact, only five of the cancer-related genes in our study have been previously reported as Runx2 targets (MMP13, CEBPA, VEGF, SMAD3, and SMAD6) and only six others are Runx1 and/or Runx3 targets (SKP2, CSF2, IL3, ACHE, IGFBP3, and HIPK2; Figure 6 ). The remaining 234 genes are therefore novel 
A
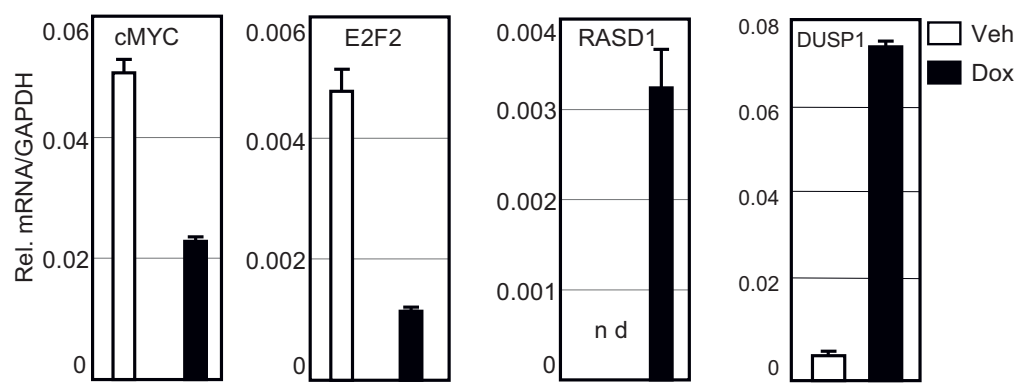

B
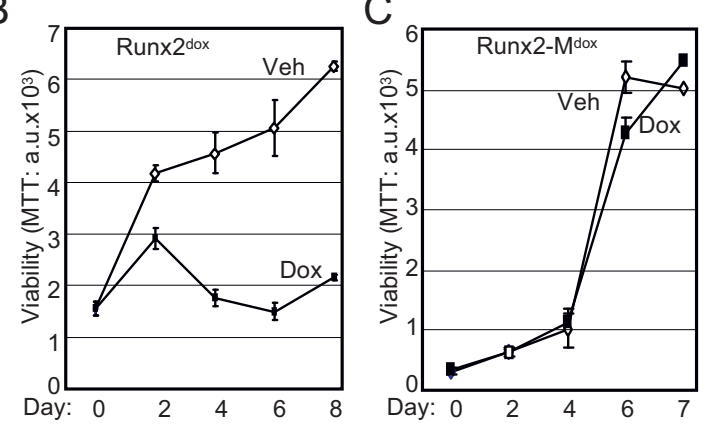

D

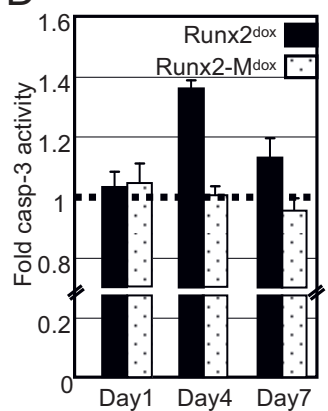

E

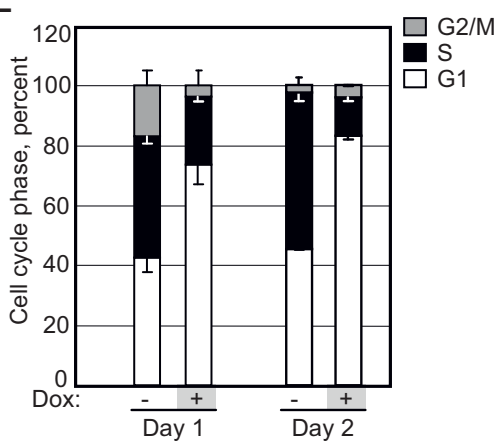

$\mathrm{F}$

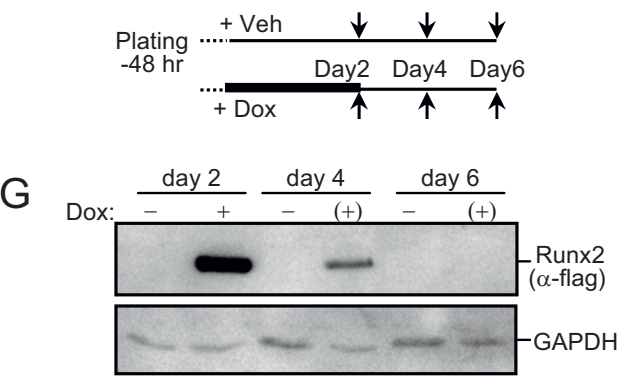

G

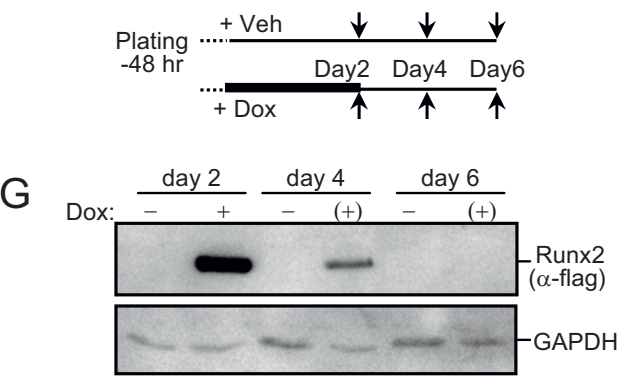

$\mathrm{H}$

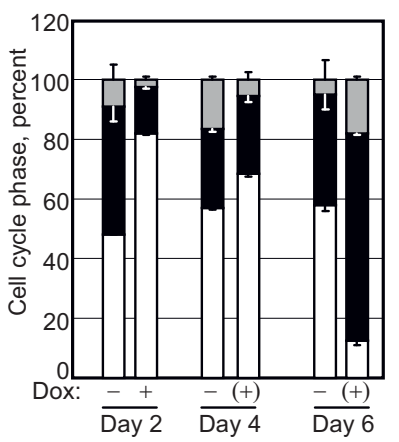

I

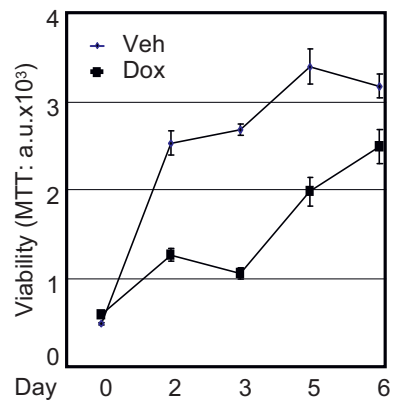

Figure 5 Runx2 inhibits the G1/S phase transition of the cell cycle. A, RT-qPCR analysis of the indicated genes in $C 4-2 B / R \times 2^{\text {dox }}$ cells treated with Dox (filled bars) or vehicle (open bars) for 48 hours. B and C, MTT-based cell proliferation assays of C4-2B/Rx $2^{\text {dox }}$ and $C 4-2 B / R \times 2-M^{\text {dox }}$ cells treated with Dox or vehicle as depicted for the indicated time periods. D, Relative apoptosis based on caspase 3 activity in whole cell extracts prepared from $\mathrm{C} 4-2 \mathrm{~B} / \mathrm{R} \times 2^{\mathrm{dox}}$ and $\mathrm{C} 4-2 \mathrm{~B} / \mathrm{R} \times 2-\mathrm{M}^{\mathrm{dox}}$ cells after treatment with Dox or vehicle for the indicated time periods. E, FACS-based cell cycle analysis of propidium iodide-stained $C 4-2 B / R \times 2^{\text {dox }}$ cells treated with Dox for the indicated time periods. F-I, Schematic description of Dox treatment and its subsequent withdrawal from the cell cultures (F). Samples were harvested th the indicated times (arrows) and subjected to analysis of Runx2 levels by western blotting (G), cell cycle profiling by FACS analysis (H), and cell proliferation by MTT assays (I). Abbreviations: RASD1, RAS, Dexamethasone-induced 1; DUSP, Dual Specificity Phosphatase. 


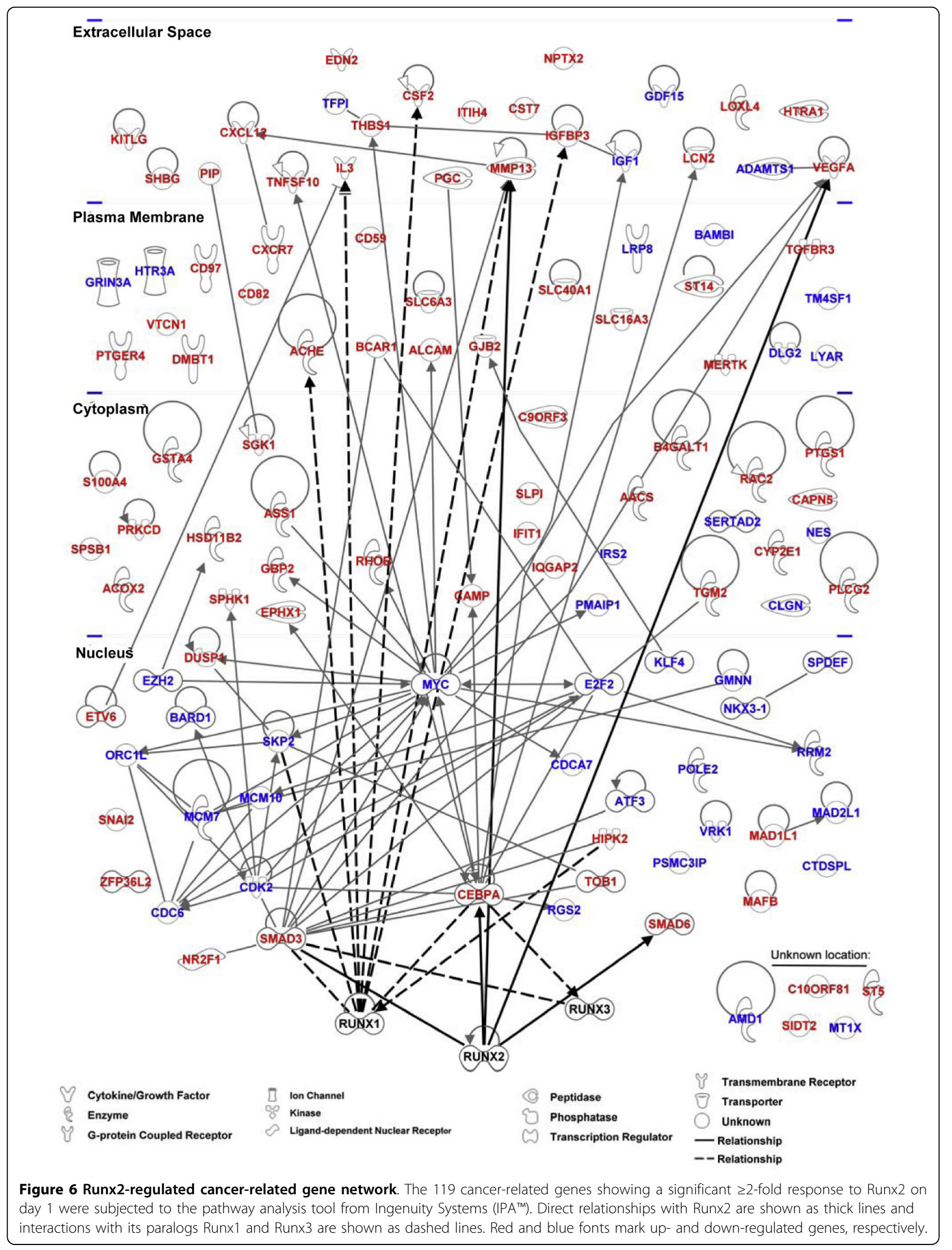


Runx2-regulated genes related to cancer in general and to metastasis in particular. The extensive Runx2-regulated cancer-related gene network highlights Runx2 as a viable target for the diagnosis, prognosis and treatment of PCa.

\section{Conclusions}

Runx2, traditionally known for its master regulatory roles in the chondro-osteoblast lineage, is emerging as a prometastatic transcription factor [22,29,34,98-101]. The Runx2 transcriptome in C4-2B cells documents gene networks that control multiple aspects of metastasis. Potentially contributing to local invasion and dissemination are the genes known to function in EMT, motility and ECM degradation. Additionally, the prometastatic function of Runx2 likely involves its target genes SDF-1, CXCR7 and BSP, which promote homing and attachment to bone. We also discovered Runx2 targets such as CSF2 and SPHK1, osteoclast activators that likely contribute to the most important alteration that occurs in the bone microenvironment in response to $\mathrm{PCa}$ metastasis, namely enhanced bone turnover. During this process, bone matrix components such as TGFß, BMPs and calcium ions are released and further fuel tumor growth and bone microenvironment modifications [102-105]. The regulation of SPHK1 by Runx2 probably potentiates additional aspects of the cancer phenotype, including angiogenesis (a function assisted by the Runx2 targets VEGFA and EDN2) and drug resistance [77,79].

The anti-mitogenic activity of Runx2 is consistent with the slow growth of PCa tumors, and may contribute to drug resistance. We imagine that future anti-Runx2 drugs will be administered along with traditional chemotherapy to eliminate cells that regain proliferative capacity. Interestingly, Runx 2 physically and functionally interacts with the receptors for androgens and estrogens $[99,101]$. Since these receptor proteins are targeted by many drugs for prostate and breast cancer, it is important to investigate their effects on Runx2-regulated transcription. Moreover, development of selective estrogen and androgen receptor modulators may benefit from consideration of their effects on Runx 2 and expression of its target genes reported in the present study.

\section{Methods}

\section{Cell culture reagents and antibodies}

C4-2B cells were obtained from ViroMed Laboratories (Minneapolis, MN). LNCaP and 22RV1 cells were from ATCC (Rockville, MD, USA). PC3 cells were also obtained from ATCC, but propagated for several years in either our laboratory ( $\left.\mathrm{PC} 3^{\text {low }}\right)$ or that of USC's Dr. Pradip Roy-Burman ( $\left.\mathrm{PC} 3^{\text {high }}\right)$. The cells were maintained in RPMI-1640 medium supplemented with 10\% Tet System Approved FBS from Clontech, CA, USA.
Hygromycin B was purchased from Invitrogen, Carlsbad, CA, USA and added to the growth medium at $50 \mu \mathrm{g} / \mathrm{ml}$. Doxycycline from Calibiochem, La Jolla, CA, USA was used at $0.25 \mathrm{ug} / \mathrm{ml}$ unless otherwise stated, and an equal volume of distilled water was used as vehicle control. Mouse ANTI-FLAG ${ }^{\circ}$ M2 monoclonal antibody for was purchased from Sigma, St Louis, MO, USA. Mouse antiRunx2 was from Invitrogen, Carlsbad, CA, USA. The anti-PIP antibody (ab 62363) was purchased from abcam Inc., Cambridge, MA; and anti-GAPDH (V-18), anti-TGFß-RIII (Sc 28975), and anti-SDF-1 (Sc-28876) antibodies were purchased from Santa Cruz Biotechnology Inc, Santa Cruz, CA, USA. The mouse monoclonal anti-Myc and anti-VEGFA antibodies were developed and kindly provided by USC's Dr. Prakash S. Gill and Dr. Young Hong, respectively. The mouse monoclonal anti-Tubulin antibody, developed by Dr. Charles Walsh, was obtained from the Developmental Studies Hybridoma Bank under the auspices of the NICHD and The University of Iowa, Department of Biological Sciences, Iowa City, USA.

\section{Plasmid construction}

The cDNA encoding mouse Runx2 (MASN isoform, type-2), which is $97 \%$ identical to human type-2 Runx2 [1], was amplified using pcDNA3.0-Runx2 as template and the Flag epitope was inserted during the PCR amplification (see primers in additional file 8). The FlagRunx2 cDNA was initially cloned into the SpeI/MfeIdigested lentiviral entry vector pEN_TmiRc3 (ATCC ${ }^{\ominus}$ catalog: MBA-248), and the resulting plasmid was recombined using Gateway ${ }^{\odot}$ LR Clonase ${ }^{\odot}$ II enzyme mix (Invitrogen, Carlsbad, CA, USA) with the pSLIK (single lentivector for inducible knockdown) destination vector carrying a hygromycin resistance gene (ATCC ${ }^{\circledR}$ catalog: MBA-237). The entry and destination vectors were kindly provided by USC's Dr. Elizabeth Lowler (Childrens Hospital Los Angeles). The DNA-binding mutant Runx2-M was constructed by site directed mutagenesis of two arginine residues at positions 265 and 268 (GRSGRGK) known to contact DNA in the crystal structure [40]. Lentiviral plasmid for constitutive Luciferase expression pCCL-c-MNDU3c-Luc-PGK-eGFP was kindly provided by USC's Dr. Michael Kahn at the Zilkha Neurogenetic Institute.

\section{Lentivirus production and infection}

For packaging, the lentiviral expression plasmids were cotransfected by the calcium chloride method into HEK293T cells along with helper plasmids pMD.G1 and pCMVR8.91[106,107]. Culture media containing viral particles were harvested after 48-72 hours and used for transduction of C4-2B cells in the presence of $8 \mu \mathrm{g} / \mathrm{ml}$ Polybrene (Millipore Corp., MA, USA). After infection 
with the lentiviruses, the transduced cells were selected with $50 \mu \mathrm{g} / \mathrm{ml}$ of Hygromycin.

\section{Transient transfection and Luciferase assays}

Transient transfection and Luciferase assays were performed essentially as described by Khalid et al. [99]. Briefly, 25,000 cells were plated in a 24-well plate 48 hours prior to transfection using Invitrogen's Lipofecta$\operatorname{mine}^{\text {tx }}$ LTX reagent according to manufacturer's instructions. Cells were harvested and subjected to luciferase assay using Luciferase Assay system from Promega, Madison, WI, USA.

\section{High throughput gene expression measurement and analysis}

Gene expression profiling was performed using the BeadChip ${ }^{\text {tw }}$ platform (Illumina) and chip reference 8 , version 3 for humans, which contains 24,526 gene probes and 664 negative control probes. Details of the raw data processing and analysis are provided in the additional file 9. Briefly, after background correction, the normalized expression intensities for all probes were subjected to a two-way analysis of variance (ANOVA) and the resulting $p$-values were adjusted for multiple testing using the Benjimini-Hochberg method [108]. The differentially expressed probes were further investigated using the Ingenuity Pathways Analysis package (IPA ${ }^{\mathrm{mw}}$; http://www.ingenuity. com) to identify biological functions and disease categories that are significantly enriched among the differentially expressed genes. Right-tailed Fisher's exact test as implemented in the IPA software was used to calculate a $p$-value for the probability of each network to be enriched for Runx2-regulated genes due to chance alone. The microarray data has been deposited to the GEO database with the accession code GSE24261.

\section{Preparation of conditioned medium and gelatin zymography}

$\mathrm{C} 4-2 \mathrm{~B} / \mathrm{Rx} 2^{\mathrm{dox}}$ cells were cultured in $10 \mathrm{~cm}$ culture dishes to $80 \%$ confluence, washed 3 times with RPMI1640 and treated with Dox in $10 \mathrm{~mL}$ of RPMI-1640 without FBS for $24 \mathrm{hrs}$. For zymography the $25 \mu \mathrm{l}$ of the conditioned media from Dox treated or control cells were analyzed by $8 \%$ acrylamide gels containing $0.1 \% \mathrm{w} /$ $\mathrm{v}$ gelatin [109] After electrophoresis, the gel was washed with $2.5 \%$ Triton X-100 and incubated in the developing buffer $(500 \mathrm{mM}$ Tris- $\mathrm{HCl}, \mathrm{pH} 7.8,2 \mathrm{M} \mathrm{NaCl}, 50 \mathrm{mM}$ $\mathrm{CaCl}_{2}$ ) overnight to induce gelatin lysis. Gel was stained by Coomasie blue-250. For western blot analysis of conditioned media, $250 \mu \mathrm{l}$ of the supernatant was TCA-precipitated and subjected to reducing SDS-PAGE analysis using standard procedures.

\section{In vitro invasion and migration assays}

Invasion through Matrige ${ }^{\mathrm{Tm}}$ was assessed by incubating 20,000 luciferase-expressing cells at the top of 24 well

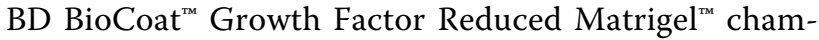
ber (BD Biosciences, MA, USA). Migration was assessed using BD BioCoat ${ }^{\text {tm }}$ Control Inserts. Cells that migrated or invaded to the bottom compartment were visualized by Diff-Quick ${ }^{\text {ti }}$ staining kit (Baxter, MN, USA) or subjected to luciferase assays for quantification. Invasion index was defined as the percentage of cells that invaded through Matrigel ${ }^{\mathrm{mi}}$ over those that migrated under the same conditions but without the Matrigel ${ }^{\mathrm{m} m}$.

\section{Proliferation, cell cycle and apoptosis}

Cultures on different days were subjected to MTT assay (Sigma, St Louis, MO) to measure viable cells in culture. For cell cycle analysis, $2 \times 10^{5}$ to $1 \times 10^{6}$ cells were harvested, washed twice with PBS $(1 \mathrm{~mL})$ at room temperature and stored in absolute ethanol $(4 \mathrm{~mL})$ for at least 24 hours. Pelleted cells were rehydrated in $5 \mathrm{~mL}$ PBS for 15 minutes, followed by staining with $1 \mathrm{~mL}$ of a propidium iodide (PI, Calibiochem, La jolla, CA, USA) solution containing $3 \mu \mathrm{M}$ PI in incubation buffer $(100 \mathrm{mM}$ Tris, $\mathrm{pH} 7.4,150 \mathrm{mM}$ $\mathrm{NaCl}, 1 \mathrm{mM} \mathrm{CaCl} 2,0.5 \mathrm{mM} \mathrm{MgCl}_{2}, 0.1 \%$ Nonidet $^{\circ} \mathrm{P}$ $40)$. The cell suspension $(1 \mathrm{~mL})$ was subjected to fluorescence-activated cell sorting (FACScaliber, Becton Dickinson, MA, USA) and each cell was assigned to the G1, S, G2 or M phase of the cell cycle based on the PI intensity and using the Multicycle v3.0 software (Phoenix Flow Systems, San Diego, CA, USA). To assess apoptosis, cells were lysed in caspase assay buffer containing $50 \mathrm{mM}$ HEPES (pH 7.5), $100 \mathrm{mM} \mathrm{NaCl}$, $2 \mathrm{mM}$ EDTA, $0.1 \%$ CHAPS, $10 \%$ sucrose, and $5 \mathrm{mM}$ DTT. Aliquots of crude cell lysate $(50 \mu$ g protein) were incubated with the caspase- 3 substrate Ac-DEVDAMC (EMD/Calbiochem, La Jolla, CA, USA) at $37^{\circ} \mathrm{C}$ for $30 \mathrm{~min}$ and the caspase- 3 activity was quantified by flow fluorimetry with excitation at $380 \mathrm{~nm}$ and emission at $440 \mathrm{~nm}$ using Victor $_{3} \mathrm{~V}^{\mathrm{sm}}$ from PerkinElmer, Shelton, CT, USA.

\section{Western blot analysis}

Between $1 \times 10^{5}$ and $2 \times 10^{5}$ cells were washed once with PBS and lysed with $200 \mu \mathrm{L}$ of incubation buffer [100 mM Tris ( $\mathrm{pH} 7.4$ ), $500 \mathrm{mM} \mathrm{NaCl}, 1 \mathrm{mM} \mathrm{CaCl}_{2}$, $0.5 \mathrm{mM} \mathrm{MgCl}_{2}, 0.1 \%$ Nonidet $^{\circ} \mathrm{P}-40$ ] supplemented with Complete $^{\mathrm{tw}}$ protease inhibitor mix (Roche Diagnostics, Indianapolis, IN, USA). Aliquots of $40 \mu \mathrm{g}$ cell lysate were mixed with an equal volume of Laemmli buffer and proteins were resolved by 10\% SDS-PAGE, transferred to Amersham Hybond ${ }^{\mathrm{m}}$-P PVDF (GE Healthcare, Piscataway, NJ, USA) membranes, and visualized using respective antibodies and the Western Lightning ${ }^{\text {ma }}$ Plus- 
ECL kit (PerkinElmer Inc, Waltham, MA, USA) followed by exposure to X-ray film (ISCBioExpress ${ }^{\ominus}$, Kaysville, UT, USA).

\section{RT-qPCR}

Total RNA was isolated using Aurum Total RNA kit (Bio-Rad Laboratories Inc., Hercules, CA, USA) following the manufacturer's recommendations and $1 \mu \mathrm{g}$ was reverse transcribed using the Superscript III kit (Invitrogen, CA, USA). The cDNA was subjected to real-time PCR amplification using iQ SYBR Green Supermix and a Opticon ${ }^{\text {max}} 2$ real time PCR machine from Bio-Rad, Hercules, CA. The sequences of primers for amplification of the cDNA of interest and the control GAPDH are listed in the additional file 8 .

GEO accession code for the microarray data: GSE24261

\section{Additional material}

Additional file 1: ANOVA analysis of the microarray data. List of all probes with the microarray gene expression data in log scale (base 2) along with the Fold change, P-values and gene annotations.

Additional file 2: Runx2-regulated genes involved in cellular metabolism. List of genes with functions in cellular metabolism, their fold changes, and known functions.

Additional file 3: Runx2 -regulated genes involved in cancer. List of 256 genes with established roles in cancer.

Additional file 4: $\mathrm{E}$-Cadherin expression in $\mathrm{C} 4-2 \mathrm{~B} / \mathrm{R} \times 2^{\mathrm{dox}}$ cells upon Runx2 expression. Western blot and RT-qPCR analysis of $C 4-2 B / R \times 2^{\text {dox }}$ cells in response to Runx2 expression.

Additional file 5: Generation and characterization of $\mathrm{LNCaP} / \mathrm{Rx} 2^{\text {dox }}$ cells. RT-PCR to detect Runx2 transcript in PC3, C4-2B, and LNCaP cells. Proliferation of the $L N C a P / R \times 2^{\text {dox }}$ cells by using MTT, and RT-qPCR analysis of Runx2-regulated genes.

Additional file 6: Generation and characterization of 22RV1/Rx2 ${ }^{\text {dox }}$ cells. Western blot analysis of Dox-induced Runx2, and MTT based proliferation analysis of $22 \mathrm{RV} 1 / \mathrm{R} \times 2^{\text {dox }}$ cells in response to Runx2 expression.

Additional file 7: Expression of PGC, CST7, S100A4, SDF-1, CSF2, and DUSP1 in two PC3 sub-lines with different Runx2 levels. RT$\mathrm{qPCR}$ analysis using $\mathrm{PC} 3^{\text {high }}$ and $\mathrm{PC} 3^{\text {low }}$ cells to examine the expression of Runx2-regulated genes.

Additional file 8: List of primers used in the present study to PCRamplify the indicated gene sequences. Nucleotide sequence of primers.

Additional file 9: Bioinformatics analysis of the microarray data. Detailed description of microarray quality control and data processing (such as quality control, normalization and box/density plots); and methodology employed for the identification of differentially expressed probes.

\section{Acknowledgements}

We thank Dr. Joseph Hacia and Dr. Nyam-Osor Chimge at the University of Southern California for their critical comments during the preparation of the manuscript. We also thank Dr. Gerard Karsenty (Columbia University, New York, NY) for the 6XOSE2-luciferase reporter and PCDNA3.1-Runx2 (mouse) plasmids. The microarray analysis was performed at the Southern California Genotyping Consortium at UCLA http://scgc.genetics.ucla.edu/ under the direction of Mr. Joseph DeYoung. Further analysis of the gene expression profiles was performed with help from Dr. Yibu Chen at the USC Norris Medical Library. We thank Dr. Shinwu Jeong and Dr. Gabriel M Gordon for their help with the zymography assay. We also thank Dr. Pradip Roy-Burman and Helty Adisetiyo for kindly providing the PC ${ }^{\text {high }}$ cell line. The anti-TGFßRIII antibody was kindly provided by Dr. Yang Chai at Center for Craniofacial Molecular Biology; and anti-SDF-1 antibody was kindly provided by Dr. Henry Sucov at the University of Southern California. This work was funded by NIH grants R01 CA 109147 and R01 CA 136924. SKB was supported by a postdoctoral Innovative Chapter Research Award; and YG by a Meyer Young Investigator Fellowship, both from the Arthritis Foundation Southern California Chapter. BF holds the J. Harold and Edna L. LaBriola Chair in Genetic Orthopedic Research at USC.

\section{Author details}

${ }^{1}$ Department of Biochemistry \& Molecular Biology, University of Southern California, Los Angeles, USA. ²Department of Orthopaedic Surgery, University of Southern California, Los Angeles, USA. ${ }^{3}$ Department of Urology, University of Southern California, Los Angeles, USA. ${ }^{4}$ Institute for Genetic Medicine, Keck School of Medicine at the University of Southern California, Los Angeles, USA. ${ }^{5}$ Norris Cancer Center, University of Southern California, Los Angeles, USA. ${ }^{6}$ Keck School of Medicine at the University of Southern California, Los Angeles, USA. ' SRA International, 2605 Meridian Parkway, Durham, USA. ${ }^{8}$ Sciome LLC, 2 Davis Drive, Research Triangle Park, USA.

\section{Authors' contributions}

Conceived and designed the experiments: SKB and BF. Performed the experiments: SKB, OK, YG, AEG, SS and DJP. Bioinformatics analysis: RRS and DM. Analyzed data and wrote the paper: SKB, GAC and BF. All authors have read and approved the final manuscript.

\section{Competing interests}

The authors declare that they have no competing interests.

Received: 8 April 2010 Accepted: 23 September 2010

Published: 23 September 2010

\section{References}

1. Ducy P, Zhang R, Geoffroy V, Ridall AL, Karsenty G: Osf2/Cbfa1: a transcriptional activator of osteoblast differentiation. Cell 1997, 89:747-754.

2. Cameron ER, Neil JC: The Runx genes: lineage-specific oncogenes and tumor suppressors. Oncogene 2004, 23:4308-4314.

3. Lo Coco F, Pisegna S, Diverio D: The AML1 gene: a transcription factor involved in the pathogenesis of myeloid and lymphoid leukemias. Haematologica 1997, 82:364-370.

4. Woolf E, Xiao C, Fainaru O, Lotem J, Rosen D, Negreanu V, Bernstein Y, Goldenberg D, Brenner O, Berke G, et al: Runx3 and Runx1 are required for CD8 T cell development during thymopoiesis. Proc Natl Acad Sci USA 2003, 100:7731-7736.

5. Komori T, Yagi H, Nomura S, Yamaguchi A, Sasaki K, Deguchi K, Shimizu Y, Bronson RT, Gao YH, Inada M, et al: Targeted disruption of Cbfa1 results in a complete lack of bone formation owing to maturational arrest of osteoblasts. Cell 1997, 89:755-764.

6. Otto F, Thornell AP, Crompton T, Denzel A, Gilmour KC, Rosewell IR, Stamp GW, Beddington RS, Mundlos S, Olsen BR, et al: Cbfa1, a candidate gene for cleidocranial dysplasia syndrome, is essential for osteoblast differentiation and bone development. Cell 1997, 89:765-771.

7. Levanon D, Bettoun D, Harris-Cerruti C, Woolf E, Negreanu V, Eilam R, Bernstein Y, Goldenberg D, Xiao C, Fliegauf M, et al: The Runx3 transcription factor regulates development and survival of TrkC dorsal root ganglia neurons. Embo J 2002, 21:3454-3463.

8. Ito Y: Oncogenic potential of the RUNX gene family: 'overview'. Oncogene 2004, 23:4198-4208.

9. Bae SC, Choi JK: Tumor suppressor activity of RUNX3. Oncogene 2004, 23:4336-4340.

10. Levanon D, Groner Y: Structure and regulated expression of mammalian RUNX genes. Oncogene 2004, 23:4211-4219.

11. Oshimo Y, Oue N, Mitani Y, Nakayama H, Kitadai Y, Yoshida K, Ito Y, Chayama K, Yasui W: Frequent loss of RUNX3 expression by promoter hypermethylation in gastric carcinoma. Pathobiology 2004, 71:137-143. 
12. Rossetti S, Van Unen L, Touw IP, Hoogeveen AT, Sacchi N: Myeloid maturation block by AML1-MTG16 is associated with Csf1r epigenetic downregulation. Oncogene 2005, 24:5325-5332.

13. Kilbey A, Blyth K, Wotton S, Terry A, Jenkins A, Bell M, Hanlon L, Cameron ER, Neil JC: Runx2 disruption promotes immortalization and confers resistance to oncogene-induced senescence in primary murine fibroblasts. Cancer Res 2007, 67:11263-11271.

14. Zaidi SK, Pande S, Pratap J, Gaur T, Grigoriu S, Ali SA, Stein JL, Lian JB, van Wijnen AJ, Stein GS: Runx2 deficiency and defective subnuclear targeting bypass senescence to promote immortalization and tumorigenic potential. Proc Natl Acad Sci USA 2007, 104:19861-19866.

15. Galindo M, Pratap J, Young DW, Hovhannisyan H, Im HJ, Choi JY, Lian JB, Stein $J$, Stein GS, van Wijnen AJ: The bone-specific expression of Runx2 oscillates during the cell cycle to support a G1-related antiproliferative function in osteoblasts. J Biol Chem 2005, 280:20274-20285.

16. Pratap J, Galindo M, Zaidi SK, Vradii D, Bhat BM, Robinson JA, Choi JY, Komori T, Stein $J$, Lian JB, et al: Cell growth regulatory role of Runx2 during proliferative expansion of preosteoblasts. Cancer Res 2003, 63:5357-5362.

17. Thomas DM, Johnson SA, Sims NA, Trivett MK, Slavin JL, Rubin BP Waring P, McArthur GA, Walkley CR, Holloway AJ, et al: Terminal osteoblast differentiation, mediated by runx2 and p27KIP1, is disrupted in osteosarcoma. J Cell Biol 2004, 167:925-934.

18. Blyth K, Terry A, Mackay N, Vaillant F, Bell M, Cameron ER, Neil JC, Stewart M: Runx2: a novel oncogenic effector revealed by in vivo complementation and retroviral tagging. Oncogene 2001, 20:295-302.

19. Blyth K, Cameron ER, Neil JC: The RUNX genes: gain or loss of function in cancer. Nat Rev Cancer 2005, 5:376-387.

20. Komori T: Regulation of osteoblast differentiation by transcription factors. J Cell Biochem 2006, 99:1233-1239.

21. Otto $F$, Kanegane $H$, Mundlos S: Mutations in the RUNX2 gene in patients with cleidocranial dysplasia. Hum Mutat 2002, 19:209-216.

22. Akech J, Wixted JJ, Bedard K, van der Deen M, Hussain S, Guise TA, van Wijnen AJ, Stein JL, Languino LR, Altieri DC, et al: Runx2 association with progression of prostate cancer in patients: mechanisms mediating bone osteolysis and osteoblastic metastatic lesions. Oncogene 2009, 811-821.

23. Koeneman KS, Yeung F, Chung LW: Osteomimetic properties of prostate cancer cells: a hypothesis supporting the predilection of prostate cancer metastasis and growth in the bone environment. Prostate 1999 39:246-261.

24. Chua CW, Chiu YT, Yuen HF, Chan KW, Man K, Wang X, Ling MT, Wong YC: Suppression of androgen-independent prostate cancer cell aggressiveness by FTY720: validating Runx2 as a potential antimetastatic drug screening platform. Clin Cancer Res 2009, 15:4322-4335.

25. Lin DL, Tarnowski CP, Zhang J, Dai J, Rohn E, Patel AH, Morris MD, Keller ET: Bone metastatic LNCaP-derivative C4-2B prostate cancer cell line mineralizes in vitro. Prostate 2001, 47:212-221.

26. Selvamurugan N, Kwok S, Partridge NC: Smad3 interacts with JunB and Cbfa1/Runx2 for transforming growth factor-beta1-stimulated collagenase-3 expression in human breast cancer cells. J Biol Chem 2004, 279:27764-27773.

27. Lim M, Zhong C, Yang S, Bell AM, Cohen MB, Roy-Burman P: Runx2 regulates survivin expression in prostate cancer cells. Lab Invest 90:222-233.

28. Pratap J, Javed A, Languino LR, van Wijnen AJ, Stein JL, Stein GS, Lian JB: The Runx2 osteogenic transcription factor regulates matrix metalloproteinase 9 in bone metastatic cancer cells and controls cell invasion. Mol Cell Biol 2005, 25:8581-8591.

29. Barnes GL, Javed A, Waller SM, Kamal MH, Hebert KE, Hassan MQ, Bellahcene A, Van Wijnen AJ, Young MF, Lian JB, et al: Osteoblast-related transcription factors Runx2 (Cbfa1/AML3) and MSX2 mediate the expression of bone sialoprotein in human metastatic breast cancer cells. Cancer Res 2003, 63:2631-2637.

30. Zelzer E, Glotzer DJ, Hartmann C, Thomas D, Fukai N, Soker S, Olsen BR: Tissue specific regulation of VEGF expression during bone development requires Cbfa1/Runx2. Mech Dev 2001, 106:97-106.

31. Geoffroy $V$, Kneissel M, Fournier B, Boyde A, Matthias P: High bone resorption in adult aging transgenic mice overexpressing cbfa1/runx 2 in cells of the osteoblastic lineage. Mol Cell Biol 2002, 22:6222-6233.

32. Maruyama Z, Yoshida CA, Furuichi T, Amizuka N, Ito M, Fukuyama R, Miyazaki T, Kitaura H, Nakamura K, Fujita T, et al: Runx2 determines bone maturity and turnover rate in postnatal bone development and is involved in bone loss in estrogen deficiency. Dev Dyn 2007, 236:1876-1890.

33. Yeung F, Law WK, Yeh CH, Westendorf JJ, Zhang Y, Wang R, Kao C, Chung LW: Regulation of human osteocalcin promoter in hormoneindependent human prostate cancer cells. J Biol Chem 2002, 277:2468-2476.

34. Pratap J, Imbalzano KM, Underwood JM, Cohet N, Gokul K, Akech J, van Wijnen AJ, Stein JL, Imbalzano AN, Nickerson JA, et al: Ectopic runx2 expression in mammary epithelial cells disrupts formation of normal acini structure: implications for breast cancer progression. Cancer Res 2009, 69:6807-6814.

35. Kayed $H$, Jiang $X$, Keleg $S$, Jesnowski R, Giese T, Berger MR, Esposito I, Lohr M, Friess H, Kleeff J: Regulation and functional role of the Runtrelated transcription factor-2 in pancreatic cancer. Br J Cancer 2007, 97:1106-1115.

36. Endo T, Ohta K, Kobayashi T: Expression and function of Cbfa-1/Runx2 in thyroid papillary carcinoma cells. J Clin Endocrinol Metab 2008, 93:2409-2412.

37. Horoszewicz JS, Leong SS, Kawinski E, Karr JP, Rosenthal H, Chu TM, Mirand EA, Murphy GP: LNCaP model of human prostatic carcinoma. Cancer Res 1983, 43:1809-1818.

38. Wu HC, Hsieh JT, Gleave ME, Brown NM, Pathak S, Chung LW: Derivation of androgen-independent human LNCaP prostatic cancer cell sublines: role of bone stromal cells. Int J Cancer 1994, 57:406-412.

39. Shin KJ, Wall EA, Zavzavadjian JR, Santat LA, Liu J, Hwang JI, Rebres R, Roach T, Seaman W, Simon MI, Fraser ID: A single lentiviral vector platform for microRNA-based conditional RNA interference and coordinated transgene expression. Proc Natl Acad Sci USA 2006, 103:13759-13764.

40. Tahirov TH, Inoue-Bungo T, Morii H, Fujikawa A, Sasaki M, Kimura K, Shiina M, Sato K, Kumasaka T, Yamamoto M, et al: Structural analyses of DNA recognition by the AML1/Runx-1 Runt domain and its allosteric control by CBFbeta. Cell 2001, 104:755-767.

41. Sudhakar S, Li Y, Katz MS, Elango N: Translational regulation is a control point in RUNX2/Cbfa1 gene expression. Biochem Biophys Res Commun 2001, 289:616-622.

42. Ducy P, Karsenty G: Two distinct osteoblast-specific cis-acting elements control expression of a mouse osteocalcin gene. Mol Cell Biol 1995, 15:1858-1869.

43. Vaes BL, Ducy P, Sijbers AM, Hendriks JM, van Someren EP, de Jong NG, van den Heuvel ER, Olijve W, van Zoelen EJ, Dechering KJ: Microarray analysis on Runx2-deficient mouse embryos reveals novel Runx2 functions and target genes during intramembranous and endochondral bone formation. Bone 2006, 39:724-738.

44. Cheung M, Chaboissier MC, Mynett A, Hirst E, Schedl A, Briscoe J: The transcriptional control of trunk neural crest induction, survival, and delamination. Dev Cell 2005, 8:179-192.

45. Yang J, Bielenberg DR, Rodig SJ, Doiron R, Clifton MC, Kung AL, Strong RK Zurakowski D, Moses MA: Lipocalin 2 promotes breast cancer progression. Proc Natl Acad Sci USA 2009, 106:3913-3918.

46. Caputo E, Manco G, Mandrich L, Guardiola J: A novel aspartyl proteinase from apocrine epithelia and breast tumors. J Biol Chem 2000, 275:7935-7941.

47. Chiang L, Contreras L, Chiang J, Ward PH: Human prostatic gastricsinogen the precursor of seminal fluid acid proteinase. Arch Biochem Biophys 1981, 210:14-20.

48. Morita M, Yoshiuchi N, Arakawa H, Nishimura S: CMAP: a novel cystatinlike gene involved in liver metastasis. Cancer Res 1999, 59:151-158.

49. Sherbet GV: Metastasis promoter S100A4 is a potentially valuable molecular target for cancer therapy. Cancer Lett 2009, 280:15-30.

50. Matsuura I, Lai CY, Chiang KN: Functional interaction between Smad3 and S100A4 (metastatin-1) for TGF-beta-mediated cancer cell invasiveness. Biochem J 2010, 426:327-335.

51. Artym W, Zhang Y, Seillier-Moiseiwitsch F, Yamada KM, Mueller SC: Dynamic interactions of cortactin and membrane type 1 matrix metalloproteinase at invadopodia: defining the stages of invadopodia formation and function. Cancer Res 2006, 66:3034-3043.

52. Larsen M, Artym W, Green JA, Yamada KM: The matrix reorganized: extracellular matrix remodeling and integrin signaling. Curr Opin Cell Biol 2006, 18:463-471. 
53. Schmidt KL, Marcus-Gueret N, Adeleye A, Webber J, Baillie D, Stringham EG: The cell migration molecule UNC-53/NAV2 is linked to the ARP2/3 complex by ABI-1. Development 2009, 136:563-574.

54. Sekerkova G, Loomis PA, Changyaleket B, Zheng L, Eytan R, Chen B, Mugnaini $E$, Bartles JR: Novel espin actin-bundling proteins are localized to Purkinje cell dendritic spines and bind the Src homology 3 adapter protein insulin receptor substrate p53. J Neurosci 2003, 23:1310-1319.

55. Riederer BM: Microtubule-associated protein 1B, a growth-associated and phosphorylated scaffold protein. Brain Res Bull 2007, 71:541-558.

56. Maul RS, Song Y, Amann KJ, Gerbin SC, Pollard TD, Chang DD: EPLIN regulates actin dynamics by cross-linking and stabilizing filaments. J Cell Biol 2003, 160:399-407.

57. Paavilainen VO, Bertling E, Falck S, Lappalainen P: Regulation of cytoskeletal dynamics by actin-monomer-binding proteins. Trends Cell Biol 2004, 14:386-394.

58. Levoye A, Balabanian K, Baleux F, Bachelerie F, Lagane B: CXCR7 heterodimerizes with CXCR4 and regulates CXCL12-mediated $G$ protein signaling. Blood 2009, 113:6085-6093.

59. Mazzinghi $B$, Ronconi $E$, Lazzeri $E$, Sagrinati $C$, Ballerini L, Angelotti ML, Parente E, Mancina R, Netti GS, Becherucci F, et al: Essential but differential role for CXCR4 and CXCR7 in the therapeutic homing of human renal progenitor cells. J Exp Med 2008, 205:479-490.

60. Kryczek I, Wei S, Keller E, Liu R, Zou W: Stroma-derived factor (SDF-1/ CXCL12) and human tumor pathogenesis. Am J Physiol Cell Physiol 2007, 292:C987-995.

61. Singh S, Singh UP, Grizzle WE, Lillard JW Jr: CXCL12-CXCR4 interactions modulate prostate cancer cell migration, metalloproteinase expression and invasion. Lab Invest 2004, 84:1666-1676.

62. Kryczek I, Lange A, Mottram P, Alvarez X, Cheng P, Hogan M, Moons L, Wei S, Zou L, Machelon V, et al: CXCL12 and vascular endothelial growth factor synergistically induce neoangiogenesis in human ovarian cancers. Cancer Res 2005, 65:465-472.

63. Taichman RS, Cooper C, Keller ET, Pienta KJ, Taichman NS, McCauley LK: Use of the stromal cell-derived factor-1/CXCR4 pathway in prostate cancer metastasis to bone. Cancer Res 2002, 62:1832-1837.

64. Ara T, Tokoyoda K, Sugiyama T, Egawa T, Kawabata K, Nagasawa T: Long-term hematopoietic stem cells require stromal cell-derived factor-1 for colonizing bone marrow during ontogeny. Immunity 2003 19:257-267.

65. Peled A, Petit I, Kollet O, Magid M, Ponomaryov T, Byk T, Nagler A, BenHur $H$, Many A, Shultz $L$, et al: Dependence of human stem cell engraftment and repopulation of NOD/SCID mice on CXCR4. Science 1999, 283:845-848.

66. Waltregny D, Bellahcene A, Van Riet I, Fisher LW, Young M, Fernandez P, Dewe W, de Leval J, Castronovo V: Prognostic value of bone sialoprotein expression in clinically localized human prostate cancer. $J$ Nat/ Cancer Inst 1998, 90:1000-1008.

67. Waltregny D, Bellahcene A, de Leval X, Florkin B, Weidle U, Castronovo V: Increased expression of bone sialoprotein in bone metastases compared with visceral metastases in human breast and prostate cancers. $J$ Bone Miner Res 2000, 15:834-843.

68. Zhang JH, Tang J, Wang J, Ma W, Zheng W, Yoneda T, Chen J: Overexpression of bone sialoprotein enhances bone metastasis of human breast cancer cells in a mouse model. Int J Oncol 2003, 23:1043-1048.

69. Jung K, Lein M, Stephan C, Von Hosslin K, Semjonow A, Sinha P, Loening SA, Schnorr D: Comparison of 10 serum bone turnover markers in prostate carcinoma patients with bone metastatic spread: diagnostic and prognostic implications. Int J Cancer 2004, 111:783-791.

70. Keller ET, Zhang J, Cooper CR, Smith PC, McCauley LK, Pienta KJ, Taichman RS: Prostate carcinoma skeletal metastases: cross-talk between tumor and bone. Cancer Metastasis Rev 2001, 20:333-349.

71. Liu H, Holm M, Xie XQ, Wolf-Watz M, Grundstrom T: AML1/Runx1 recruits calcineurin to regulate granulocyte macrophage colony-stimulating factor by Ets1 activation. J Biol Chem 2004, 279:29398-29408.

72. Park BK, Zhang H, Zeng Q, Dai J, Keller ET, Giordano T, Gu K, Shah V, Pei L, Zarbo RJ, et al: NF-kappaB in breast cancer cells promotes osteolytic bone metastasis by inducing osteoclastogenesis via GM-CSF. Nat Med 2007, 13:62-69.

73. Grivennikov SI, Greten FR, Karin M: Immunity, inflammation, and cancer. Cell 2010, 140:883-899.
74. Dranoff G: Cytokines in cancer pathogenesis and cancer therapy. Nat Rev Cancer 2004, 4:11-22.

75. Greten FR, Eckmann L, Greten TF, Park JM, Li ZW, Egan LJ, Kagnoff MF Karin M: IKKbeta links inflammation and tumorigenesis in a mouse model of colitis-associated cancer. Cell 2004, 118:285-296.

76. Ishii M, Egen JG, Klauschen F, Meier-Schellersheim M, Saeki Y, Vacher J, Proia RL, Germain RN: Sphingosine-1-phosphate mobilizes osteoclast precursors and regulates bone homeostasis. Nature 2009, 458:524-528.

77. Shida D, Takabe K, Kapitonov D, Milstien S, Spiegel S: Targeting SphK1 as a new strategy against cancer. Curr Drug Targets 2008, 9:662-673.

78. Visentin B, Vekich JA, Sibbald BJ, Cavalli AL, Moreno KM, Matteo RG, Garland WA, LU Y, YU S, Hall HS, et al: Validation of an anti-sphingosine-1phosphate antibody as a potential therapeutic in reducing growth, invasion, and angiogenesis in multiple tumor lineages. Cancer Cell 2006, 9:225-238.

79. Pchejetski D, Golzio M, Bonhoure E, Calvet C, Doumerc N, Garcia V, Mazerolles C, Rischmann P, Teissie J, Malavaud B, Cuvillier O: Sphingosine kinase- 1 as a chemotherapy sensor in prostate adenocarcinoma cell and mouse models. Cancer Res 2005, 65:11667-11675.

80. Sadikovic B, Thorner P, Chilton-Macneill S, Martin JW, Cervigne NK, Squire J, Zielenska M: Expression analysis of genes associated with human osteosarcoma tumors shows correlation of RUNX2 overexpression with poor response to chemotherapy. BMC Cancer 10:202.

81. Vanhara P, Lincova E, Kozubik A, Jurdic P, Soucek K, Smarda J: Growth/ differentiation factor-15 inhibits differentiation into osteoclasts-a novel factor involved in control of osteoclast differentiation. Differentiation 2009, 78:213-222.

82. Pratap J, Lian JB, Javed A, Barnes GL, van Wijnen AJ, Stein JL, Stein GS Regulatory roles of Runx 2 in metastatic tumor and cancer cell interactions with bone. Cancer Metastasis Rev 2006, 25:589-600.

83. Teplyuk NM, Haupt LM, Ling L, Dombrowski C, Mun FK, Nathan SS, Lian JB, Stein JL, Stein GS, Cool SM, van Wijnen AJ: The osteogenic transcription factor Runx2 regulates components of the fibroblast growth factor/ proteoglycan signaling axis in osteoblasts. J Cell Biochem 2009, 107:144-154

84. Essner JJ, Chen E, Ekker SC: Syndecan-2. Int J Biochem Cell Biol 2006, 38:152-156.

85. Park H, Kim Y, Lim Y, Han I, Oh ES: Syndecan-2 mediates adhesion and proliferation of colon carcinoma cells. J Biol Chem 2002, 277:29730-29736.

86. Granes F, Urena JM, Rocamora N, Vilaro S: Ezrin links syndecan-2 to the cytoskeleton. J Cell Sci 2000, 113(Pt 7):1267-1276.

87. Nelson JB, Hedican SP, George DJ, Reddi AH, Piantadosi S, Eisenberger MA, Simons JW: Identification of endothelin-1 in the pathophysiology of metastatic adenocarcinoma of the prostate. Nat Med 1995, 1:944-949.

88. Dai J, Kitagawa Y, Zhang J, Yao Z, Mizokami A, Cheng S, Nor J, McCauley LK, Taichman RS, Keller ET: Vascular endothelial growth factor contributes to the prostate cancer-induced osteoblast differentiation mediated by bone morphogenetic protein. Cancer Res 2004, 64:994-999.

89. Street J, Bao M, deGuzman L, Bunting S, Peale FV Jr, Ferrara N, Steinmetz H, Hoeffel J, Cleland JL, Daugherty A, et al: Vascular endothelial growth factor stimulates bone repair by promoting angiogenesis and bone turnover. Proc Natl Acad Sci USA 2002, 99:9656-9661.

90. Cross MJ, Claesson-Welsh L: FGF and VEGF function in angiogenesis: signalling pathways, biological responses and therapeutic inhibition. Trends Pharmacol Sci 2001, 22:201-207.

91. Ferrara N, Gerber HP, LeCouter J: The biology of VEGF and its receptors. Nat Med 2003, 9:669-676.

92. Vaidyanathan G, Cismowski MJ, Wang G, Vincent TS, Brown KD, Lanier SM: The Ras-related protein AGS1/RASD1 suppresses cell growth. Oncogene 2004, 23:5858-5863.

93. Horsch K, de Wet H, Schuurmans MM, Allie-Reid F, Cato AC, Cunningham J, Burrin JM, Hough FS, Hulley PA: Mitogen-activated protein kinase phosphatase 1/dual specificity phosphatase 1 mediates glucocorticoid inhibition of osteoblast proliferation. Mol Endocrinol 2007, 21:2929-2940.

94. Sramkoski RM, Pretlow TG, Giaconia JM, Pretlow TP, Schwartz S, Sy MS, Marengo SR, Rhim JS, Zhang D, Jacobberger JW: A new human prostate carcinoma cell line, 22Rv1. In Vitro Cell Dev Biol Anim 1999, 35:403-409.

95. Hecht J, Seitz V, Urban M, Wagner F, Robinson PN, Stiege A, Dieterich C, Kornak U, Wilkening U, Brieske $N$, et al: Detection of novel skeletogenesis target genes by comprehensive analysis of a Runx2(-/-) mouse model. Gene Expr Patterns 2007, 7:102-112. 
96. Young DW, Hassan $M Q$, Yang $X Q$, Galindo $M$, Javed A, Zaidi SK, Furcinitti $P$, Lapointe D, Montecino $M$, Lian JB, et al: Mitotic retention of gene expression patterns by the cell fate-determining transcription factor Runx2. Proc Natl Acad Sci USA 2007, 104:3189-3194.

97. Wotton S, Terry A, Kilbey A, Jenkins A, Herzyk P, Cameron E, Neil JC: Gene array analysis reveals a common Runx transcriptional programme controlling cell adhesion and survival. Oncogene 2008, 27:5856-5866.

98. Shore P: A role for Runx2 in normal mammary gland and breast cancer bone metastasis. J Cell Biochem 2005, 96:484-489.

99. Khalid O, Baniwal SK, Purcell DJ, Leclerc N, Gabet Y, Stallcup MR, Coetzee GA, Frenkel B: Modulation of Runx2 activity by estrogen receptor-alpha: implications for osteoporosis and breast cancer. Endocrinology 2008, 149:5984-5995.

100. Javed A, Barnes GL, Pratap J, Antkowiak T, Gerstenfeld LC, van Wijnen AJ, Stein $J$, Lian JB, Stein GS: Impaired intranuclear trafficking of Runx2 (AML3/CBFA1) transcription factors in breast cancer cells inhibits osteolysis in vivo. Proc Natl Acad Sci USA 2005, 102:1454-1459.

101. Baniwal SK, Khalid O, Sir D, Buchanan G, Coetzee GA, Frenkel B: Repression of Runx2 by androgen receptor (AR) in osteoblasts and prostate cancer cells: AR binds Runx2 and abrogates its recruitment to DNA. Mol Endocrinol 2009, 23:1203-1214.

102. Morrissey C, Vessella RL: The role of tumor microenvironment in prostate cancer bone metastasis. J Cell Biochem 2007, 101:873-886.

103. Roodman GD: Mechanisms of bone metastasis. N Engl J Med 2004, 350:1655-1664.

104. Mundy GR: Metastasis to bone: causes, consequences and therapeutic opportunities. Nat Rev Cancer 2002, 2:584-593.

105. Logothetis CJ, Lin SH: Osteoblasts in prostate cancer metastasis to bone. Nat Rev Cancer 2005, 5:21-28.

106. Phillips JE, Garcia AJ: Retroviral-mediated gene therapy for the differentiation of primary cells into a mineralizing osteoblastic phenotype. Methods Mol Biol 2008, 433:333-354

107. Kim JH, Yang CK, Heo K, Roeder RG, An W, Stallcup MR: CCAR1, a key regulator of mediator complex recruitment to nuclear receptor transcription complexes. Mol Cell 2008, 31:510-519.

108. Benjamini $Y$, Hochberg $Y$ : Controlling the false discovery rate: a practical and powerful approach to multiple testing. Journal of the Royal Statistical Society Series B 1995, 57:289-300.

109. Toth M, Fridman R: Assessment of Gelatinases (MMP-2 and MMP-9 by Gelatin Zymography. Metastasis Research Protocols 2008, 57:163-174.

110. Thiery JP: Epithelial-mesenchymal transitions in tumour progression. Nat Rev Cancer 2002, 2:442-454.

111. Dang CV, O'Donnell KA, Zeller Kl, Nguyen T, Osthus RC, Li F: The c-Myc target gene network. Semin Cancer Biol 2006, 16:253-264.

112. Guccione E, Martinato F, Finocchiaro G, Luzi L, Tizzoni L, Dall'Olio V, Zardo G, Nervi C, Bernard L, Amati B: Myc-binding-site recognition in the human genome is determined by chromatin context. Nat Cell Biol 2006, 8:764-770.

113. Burns JM, Summers BC, Wang Y, Melikian A, Berahovich R, Miao Z Penfold ME, Sunshine MJ, Littman DR, Kuo CJ, et al: A novel chemokine receptor for SDF-1 and I-TAC involved in cell survival, cell adhesion, and tumor development. J Exp Med 2006, 203:2201-2213.

114. Bellou S, Hink MA, Bagli E, Panopoulou E, Bastiaens PI, Murphy C, Fotsis T: VEGF autoregulates its proliferative and migratory ERK1/2 and p38 cascades by enhancing the expression of DUSP1 and DUSP5 phosphatases in endothelial cells. Am J Physiol Cell Physiol 2009, 297 C1477-1489.

115. Liu F, Verin AD, Wang P, Day R, Wersto RP, Chrest FJ, English DK, Garcia JG: Differential regulation of sphingosine-1-phosphate- and VEGF-induced endothelial cell chemotaxis. Involvement of G(ialpha2)-linked Rho kinase activity. Am J Respir Cell Mol Biol 2001, 24:711-719.

116. Liu Y, Wada R, Yamashita T, Mi Y, Deng CX, Hobson JP, Rosenfeldt HM, Nava VE, Chae SS, Lee MJ, et al: Edg-1, the G protein-coupled receptor for sphingosine-1-phosphate, is essential for vascular maturation. J Clin Invest 2000, 106:951-961.

117. Donaudy F, Zheng L, Ficarella R, Ballana E, Carella M, Melchionda S, Estivill X, Bartles JR, Gasparini P: Espin gene (ESPN) mutations associated with autosomal dominant hearing loss cause defects in microvillar elongation or organisation. J Med Genet 2006, 43:157-161.

118. Bartles JR, Wierda A, Zheng L: Identification and characterization of espin, an actin-binding protein localized to the F-actin-rich junctional plaques of Sertoli cell ectoplasmic specializations. J Cell Sci 1996, 109(Pt 6):1229-1239.

119. Gu C, Rodriguez ER, Reimert DV, Shu T, Fritzsch B, Richards $L$, Kolodkin AL, Ginty DD: Neuropilin-1 conveys semaphorin and VEGF signaling during neural and cardiovascular development. Dev Cell 2003, 5:45-57.

120. Singh R, Bandyopadhyay D: MUC1: a target molecule for cancer therapy. Cancer Biol Ther 2007, 6:481-486.

121. Tanner SL, Franzen R, Jaffe H, Quarles RH: Evidence for expression of some microtubule-associated protein $1 \mathrm{~B}$ in neurons as a plasma membrane glycoprotein. J Neurochem 2000, 75:553-562

122. Stylli SS, Stacey TT, Verhagen AM, Xu SS, Pass I, Courtneidge SA, Lock P: Nck adaptor proteins link Tks5 to invadopodia actin regulation and ECM degradation. J Cell Sci 2009, 122:2727-2740.

123. Donalies $M$, Cramer M, Ringwald M, Starzinski-Powitz A: Expression of $M$ cadherin, a member of the cadherin multigene family, correlates with differentiation of skeletal muscle cells. Proc Natl Acad Sci USA 1991, 88:8024-8028.

124. Hu SI, Carozza M, Klein M, Nantermet P, Luk D, Crowl RM: Human HtrA, an evolutionarily conserved serine protease identified as a differentially expressed gene product in osteoarthritic cartilage. J Biol Chem 1998, 273:34406-34412.

doi:10.1186/1476-4598-9-258

Cite this article as: Baniwal et al:: Runx2 transcriptome of prostate cancer cells: insights into invasiveness and bone metastasis. Molecular Cancer 2010 9:258.

\section{Submit your next manuscript to BioMed Central and take full advantage of:}

- Convenient online submission

- Thorough peer review

- No space constraints or color figure charges

- Immediate publication on acceptance

- Inclusion in PubMed, CAS, Scopus and Google Scholar

- Research which is freely available for redistribution

Submit your manuscript at www.biomedcentral.com/submit
C) Biomed Central 